\title{
UPAYA MENINGKATKAN HASIL BELAJAR SISWA DENGAN MODEL PEMBELAJARAN KOOPERATIF TIPE SNOWBALL THROWING PADA MATERI DAUR HIDUP HEWAN
}

\author{
Nur Elisa, Muthmainnah dan Syifa Saputra \\ Universitas Almuslim, Bireuen-Aceh \\ Syifa.mpbiounsyiah@gmail.com
}

\begin{abstract}
ABSTRAK
Penelitian ini dilatar belakangi dari rendahnya hasil belajar siswa disebabkan kebanyakan siswa ketika pembelajaran berlangsung melakukan aktivitas diluar aktifitas belajar, seperti berbicara dengan teman sebangku, mengganggu teman-teman di belakang atau didepan bangku ketika proses belajar-mengajar. Tujuan dalam penelitian ini adalah untuk mengetahui:peningkatan hasil belajar siswa, aktivitas guru dan siswa serta respon siswa dengan model pembelajaran kooperatif tipe Snowball Throwing pada konsep daur hewan di Kelas IV SD Negeri 3 Bireuen. Pendekatan yang digunakan pendekatan kualitatif dengan jenis penelitian tindakan kelas. Subjek penelitian siswa kelas IV SD Negeri 3 Bireuen berjumlah 31 siswa. Teknik pengumpulan tes, lembar obsevasi dan angket. Teknik analisis data menggunakan hasil tes, hasil observasi dan respon. Hasil Penelitian diperoleh bahwa(1) Hasil ketuntas belajar siswa pada siklus I diperoleh $64,52 \%$ dan siklus II diperoleh 87,10\% mengalami peningkatan sebesar 30\%. (2) Hasil aktivitas guru pada siklus I 75,197\% menjadi 94,45\% pada siklus II sedangkan aktivitas siswa pada siklus I 75,27\% menjadi 92,22\% pada siklus II. (3) Hasil respon siswa pada model pembelajaran Snowball Throwing pada materi materi daur hidup hewan sudah sangat baik ini terlihat dari persentase senang pada jawaban angket yang diberikan guru sebesar 72,69\% sedangkan tidak senang sebesar $27,31 \%$. Hal ini menujukkan bahwa proses pembelajaran yang dilaksanakan menggunakan model pembelajaran Snowball Throwing pada materi materi daur hidup hewan sangat baik dalam menunjang pembelajaran di kelas.
\end{abstract}

Kata Kunci: Hasil belajar, model Snowball Throwing, daur hidup hewan 


\section{BAB 1. PENDAHLUAN}

\subsection{Latar Belakang}

Pendidikan adalah bagian dari pembangunan Nasional yang merupakan keinginan dan kehendak seseorang atau sekelompok masyarakat. Pendidikan nasional dalam hal ini berfungsi untuk mengembangkan kemampuan dan membentuk pola pikir dalam membangun peradaban bangsa serta mencerdaskan mencerdaskan kehidupan bangsa, sedangkan dalam tujuannya pendidikan berupaya untuk mengembangkan potensi peserta didik agar menjadi manusia yang tunduk dan patuh terhadap peraturan, berakhlak mulia, sehat, berilmu, cakap, kreatif, mandiri, demokratis serta bertanggung jawab. Peningkatan mutu pendidikan selalu menjadi isu sentral dalam penyelenggaraan Sistem Pendidikan Nasional. Dalam upaya meningkatkan kualitas pendidikan diperlukan suatu pemerataan kesempatan belajar sehingga akan adanya peningkatan relevansi dan efisiensi (Mulyasa, 2009).

Peran Institusi pendidikan dalam melaksanakan proses pembelajaran adanya proses perencanaan, pelaksanaan dan evaluasi, sehingga dapat menjadi alat kontrol untuk mencapai tujuan pembelajaran dan siswa sebagai pusat pembelajaran mampu menjadi manusia bermoral dan berpengetahuan.

Informasi lain yang diperoleh dari guru IPA di SD Negeri 3 Bireuen, pembelajaran IPA telah dilaksanakan dengan metode diskusi di kelas. Akan tetapi saat diskusi berlangsung, hanya beberapa siswa yang benar-benar melakukan diskusi dan mendengarkan. Siswa yang lainnya sibuk dengan aktivitas lain diluar diskusi. Ini tentunya menjadi salah satu kendala dalam pembelajaran, siswa lain juga akan terganggu dan hasil pembelajaran pun tidak optimal. Selain hasil belajar tidak optimal interaksi antar siswa dan interaksi dengan guru tidak terjalin dengan baik.

Observasi dan wawancara yang dilakukan di SD Negeri 3 Bireuen diperoleh bahwa hasil belajar siswa masih rendah, terbukti dari 31 siswa yang mengikuti pelajaran hanya 18 siswa dengan persentase 58,06\% yang memperoleh nilai ketuntasan mencapai nilai KKM yaitu 70 . Disebabkan karena siswa tidak tertarik terhadap mata pelajaran IPA yang diberikan. Guru cenderung menggunakan metode ceramah sehingga proses pembelajaran hanya berjalan satu arah. Selain itu juga kebanyakan siswa ketika KBM berlangsung melakukan aktivitas diluar aktifitas belajar, seperti berbicara dengan teman sebangku, mengganggu teman-teman di belakang atau didepan bangku ketika proses belajar-mengajar. Selain itu keterapilan proses siswa 
untuk setiap materi pelajaran IPA kurang dapat memberikan kesan yang baik sehingga lebih cenderung tidak dapat mengaplikasikan dalam kehidupan sehari-hari. Hal inilah yang menyebabkan aktivitas siswa dalam belajar pun tidak ada. Siswa hanya mendengarkan setiap penjelasan-penjelasan dari guru tanpa dirangsang untuk melakukan suatu kegiatan yang dapat meningkatkan aktivitas dalam belajar. Kompetensi tersebut diperlukan agar peserta didik dapat memiliki kemampuan memperoleh, mengelola, dan memanfaatkan informasi untuk bertahan hidup pada keadaan yang selalu berubah, tidak pasti, dan kompetitif.

Untuk memecahkan masalah tersebut, maka peneliti memilih salah satu model pembelajaran yaitu model pembelajaran kooperatif tipe Snowball Throwing. Prinsipnya model pembelajaran kooperatif tipe ini membagi siswa menjadi beberapa kelompok kecil. Setiap kelompok mempunyai satu orang ketua yang akan bertugas untuk menjelaskan materi yang diberikan guru kepada anggota kelompoknya. Lalu tiap siswa menulis satu pertanyaan dan dilempar seperti bola salju kepada siswa yang lain. Pembagian kelompok bertujuan agar siswa dapat berkolaborasi dengan teman, lingkungan dan guru sehingga diharapkan setiap siswa akan siap dalam kegiatan pembelajaran dan merangsang siswa untuk belajar baik belajar dari guru maupun belajar dari siswa yang lain.

Berdasarkan permasalahan tersebut maka peneliti melakukan penelitian dengan judul "Upaya Meningkatkan Hasil Belajar Siswa dengan Model Pembelajaran Kooperatif Tipe Snowball Throwing pada Materi Daur Hidup Hewan di Kelas IV SD Negeri 3 Bireuen”.

\subsection{Identifikasi Masalah}

a. Rendahnya hasil belajar siswa kelas IV SD Negeri 3 Bireuen terhadap pembelajaran IPA yang berpengaruh pada kognitif, afektif dan psikomotor IPA.

b. Hasil belajar siswa masih dibawah kriteria ketuntasan minimal (KKM) khususnya pada materi daur hidup hewan

\subsection{Tujuan}

a. Untuk mengetahui peningkatan hasil belajar siswa dengan model pembelajaran kooperatif tipe Snowball Throwing pada konsep daur hewan di Kelas IV SD Negeri 3 Bireuen.

b. Untuk mengetahui peningkatan aktivitas guru dan siswa pada konsep daur hewan dengan model pembelajaran kooperatif tipe Snowball Throwing di Kelas IV SD Negeri 3 Bireuen. 


\section{BAB 2. KAJIAN PUSTAKA}

\subsection{Hakikat Pembelajaran IPA}

Pembelajaran IPA pada hakikatnya merupakan suatu proses untuk menghantarkan siswa ke tujuan belajarnya, dan IPA itu sendiri berperan sebagai alat untuk mencapai tujuan tersebut. IPA sebagai ilmu dapat diidentifikasikan melalui objek, benda alam, persoalan/gejala yang ditunjukkan oleh alam, serta proses keilmuan dalam menemukan konsep-konsep IPA. IPA merupakan salah satu ilmu dasar yang ikut menentukan kemajuan dan perkembangan ilmu pengetahuan dan teknologi, karena dengan belajar IPA kita akan mempunyai kemampuan berpikir logis, sistematis dan kreatif dalam memecahkan masalah (Priyadi, 2010).

Priyadi (2010) berpendapat bahwa IPA merupakan salah satu ilmu dasar yang ikut menentukan kemajuan perkembangan ilmu pengetahuan dan teknologi, karena dengan belajar IPA kita akan mempunyai kemampuan berpikir logis serta memperoleh ketrerampilan dalam berpikir kritis, sistematis dan kreatif dalam memecahkan masalah. IPA sangat berpengaruh dan berguna bagi kehidupan manusia. IPA banyak digunakan untuk berbagai bidang kehidupan seperti pertanian, peternakan, perikanan, kedokteran, dan lain sebagainya (Sheizan,2007).

Berdasarkan beberapa pengertian di atas, maka dapat disimpulkan proses pembelajaran IPA merupakan penciptaan situasi dan kondisi yang kondusif sehingga terjadi interaksi antara subjek didik dengan objek belajarnya yang berupa makhluk hidup dan segala aspek kehidupannya. Melalui interaksi antara subjek didik dengan objek belajar dapat menyebabkan perkembangan proses mental dan sensori motorik yang optimal pada diri siswa.

\subsection{Pengertian Hasil Belajar}

Hasil belajar merupakan bagian terpenting dalam pembelajaran, merupakan hasil dari suatu interaksi tindak belajar dan tindak mengajar. Dari sisi guru, tindak mengajar diakhiri dengan proses evaluasi hasil belajar. Dari sisi siswa, hasil belajar merupakan berakhirnya pengajaran dari puncak proses belajar.

Menurut Bloom (Suprijono, 2009: 6) hasil belajar mencakup kemampuan kognitif, afektif, dan psikomotorik. Yang terjadi pada perubahan perilaku secara keseluruhan bukan hanya aspek potensi kemanusiaan saja. Hasil belajar disini adalah menjelaskan bagaimana siswa belajar dan mampu menguasai setiap pembelajaran yang diterima secara langsung dan tidak langsung.

Tingkat capaian dari suatu proses pembelajaran memerluka penilaian baik yang dilakukan secara lisan maupun tulisan. Analisis hasil belajar dapat dilakukan dengan 2 cara yaitu analisis 
keakuratan instrumen yang digunakan untuk melakukan penilaian dan analisis tingkat ketuntasan yang dicapai oleh siswa. (Kunandar, 2013: 13)

Gagne (Surya, 2015:1) menyebutkan bahwa "strategi kognitif merupakan salah satu hasil pembelajaran yang paling penting berupa keterampilan dalam mengatur proses internal dalam penghampiran, pemahaman, mengingat, dan berpikir". Hasil belajar merupakan pencapaian tujuan pendidikan pada siswa yang mengikuti proses belajar mengajar. Tujuna pendidikan direncana untuk dapat mencapai dalam proses belajar mengajar. Hasil belajar merupakan realisasi tercapainnya tujuan pendidikan, sehingga hasil belajar yang diukur sangat tergantung kepada tujuan pendidikannya. (Purwanto, 2011: 46). Oleh karena itu, hasil belajar adalah suatu penilaian akhir dari proses dan pengenalan yang telah di lakukan berulang-ulang yang akan tersimpan dalam jangka waktu lama atau bahkan tidak akan hilang selama-lamanya karena hasil belajar turut serta dalam membentuk pribadi individu yang selalu ingin mencapai hasil yang lebih baik lagi sehingga akan merubah cara berpikir serta menghasilkan prilaku kerja yang lebih baik.

\subsection{Faktor-Faktor yang Mempengaruhi Hasil Belajar}

Menurut Syah, (2015:145) faktor-faktor yang mempengaruhi belajar banyak jenisnya, tetapi dapat digolongkan menjadi dua golongan saja, yaitu faktor internal dan faktor eksternal.

1. Faktor-faktor internal.

a) Aspek Fisiologi,

Kondisi organ tubuh yang lemah, apabila jika disertai pusing kepala berat, dapat menurunkan kualitas ranah cipta (kognitif) sehingga materi pelajaran kurang berbekas saat dipelajari.

Kondisi oragn-organ khusus siswa seperti tingkat kesehatan indera pendegaran dan indera penglihatan dan kemampuan meneyerap materi.

b) Aspek Psikologi yaitu:

Pembagian aspek psikologi dapat dibagi sebagai berikut:

(1) Inteligensi, inteligensi besar pengaruhnya terhadap kemajuan belajar

(2) Sikap siswa, berupa kecedenrungan untuk meraksi dan merespons dengan cara refatif pada objek orang

(3) Bakat siswa, kemampuanpotensial yang dimiliki seseorang untuk mencapai keberhasilan. 
(4) Minat Siswa, kecendrungan dan kegairahan yang tinggi dan besar pada sesuatu.

(5) Motivasi siswa, keadaan internal organisme baik manusia ataupun hewan yang mendorongnya untuk membuat sesuatu.

2. Faktor-faktor ekternal

a) Lingkungan Sosial, seperti para guru, para staf administrasi, dan teman-teman sekelas dapat mempengaruhi semangat belajar seorang siswa.

b) Lingkungan Nonsosial, gedung sekolah dan letaknya, rumah tempat tinggal keluarga siswa dan letaknya, alat-alat belajar, keadaan cuaca dan waktu belajar yang digunakan siswa.

c) Faktor Pendekatan Belajar, segala cara atau strategi yang digunakan siswa dalam menunjang keefektifan dan efisiensi proses pembelajaran materi tertentu.

\subsection{Model pembelajaran Snowball Throwing}

\section{a. Pengertian}

Model Snowball Throwing merupakan salah satu model pembelajaran yang dikembangkan berdasarkan pendekatan kontekstual. Snowball Throwing yang menurut asal katanya berarti "bola salju" dapat diartikan sebagai model pembelajaran dengan menggunakan bola pertanyaan dari kertas yang di gulung bulat berbentuk bola kemudian dilemparkan secara bergiliran di antara sesama kelompok. Suprijono, (2009: 8) mengatakan Snowball throwing adalah suatu cara penyajian bahan pelajaran dimana murid dibentuk dalam beberapa kelompok yang heterogen kemudian masing-masing kelompok dipilih ketua kelompoknya untuk mendapat tugas dari guru lalu masing-masing murid membuat pertanyaan yang dibentuk seperti bola (kertas pertanyaan) kemudian dilempar ke murid lain yang masing-masing murid menjawab pertanyaan dari bola yang diperoleh.

Model pembelajaran Snowball Throwing merupakan salah satu model pembelajaran yang dikemas dalam suatu permainan menarik yaitu saling melemparkan bola dari kertas yang berisi pertanyaan. Dalam model pembelajaran ini ditekankan pada kemampuan peserta didik untuk merumuskan suatu pertanyaan tentang materi pembelajaran yang disajikan. Pembelajaran yang dikemas dalam permainan ini membutuhkan suatu kemampuan sederhana, sehingga dapat dilakukan oleh seluruh peserta didik. Selain itu, kemampuan peserta didik dalam bekerja sama dengan teman maupun kemampuan individunya dapat diukur melalui model pembelajaran ini (Wahyuningsih, 2012:2) 
Berdasarkan uraian di atas dapat disimpulkan bahwa pembelajaran Snowball Throwing adalah suatu model pembelajaran yang membagi murid dalam beberapa kelompok, yang nantinya masing-masing anggota kelompok membuat sebuah pertanyaan pada selembar kertas dan membentuknya seperti bola, kemudian bola tersebut dilempar ke murid yang lain selama durasi waktu yang ditentukan, yang selanjutnya masing-masing murid menjawab pertanyaan dari bola yang diperolehnya.

\section{b. Langkah-langkah Pembelajaran Snowball Throwing}

Menurut Suprijono (2009) langkah-langkah model Snowball Throwing adalah:

1. Guru menyampaikan materi yang akan disajikan, dan kompotensi dasar yang ingin dicapai.

2. Guru membentuk siswa berkelompok, lalu memanggil masing-masing ketua kelompok untuk memberikan penjelasan tentang materi.

3. Masing-masing ketua kelompok kembali ke kelompoknya masing-masing, kemudian menjelaskan materi yang disampaikan oleh guru kepada temannya.

4. Kemudian masing-masing siswa diberikan satu lembar kertas kerja, untuk menuliskan satu lembar kertas kerja, untuk menuliskan satu pertanyaan apa saja yang menyangkut materi yang sudah dijelaskan oleh ketua kelompok

5. Kemudian kertas yang berisi pertanyaan tersebut dibuat seperti bola dan dilempar dari satu siswa kesiswa yang lain selama 5 menit

6. Setelah siswa dapat satu bola/ satu pertanyaan diberikan kesempatan kepada siswa untuk menjawab pertanyaan yang tertulis dalam kertas berbetuk bola tersebut secara bergantian

7. Guru memberikan kesimpulan

8. Evaluasi

9. Penutup

Terdapat beberapa manfaat yang dapat diperoleh dalam model pembelajaran Snowball Throwing diantaranya ada unsur permainan yang menyebabkan metode ini lebih menarik perhatian murid.

\section{c. Kelebihan dan Kelemahan Model Pembelajaran Snowball Throwing}

1. Kelebihan Model Snowball Throwing 
Menurut Dewi (2013:4) model Snowball Throwing mempunyai beberapa kelebihan yang semuanya melibatkan dan mengikuti pelajaran oleh siswa dalam pembelajaran. Kelebihan dari model Snowball Throwing adalah:

1) Suasana pembelajaran menjadi menyenagkan karena siswa seperti bermain dengan melempar bola kertas kepada siswa lain.

2) Siswa mendapat kesempatan untuk mengembangkan kemampuan berfikir karena diberi kesempatan untuk membuat soal dan diberikan kepada siswa lain.

3) Membuat siswa siap dengan berbagai kemungkinan karena siswa tidak tahu yang dibuat temannya seperti apa.

4) Siswa terlibat aktif dalam pembelajaran.

5) Pendidik tidak terlalu repot membuat media karena siswa terjun langsung dalam praktek.

6) Pembelajaran menjadi lebih efektif.

7) Ketiga aspek yaitu aspek kognitif dapat tercapai.

2. Kelemahan /Kekurangan Model Snowball Throwing

Menurut Dewi (2013:4) kelebihan tentu saja model Snowball Throwing juga mempunyai kekurangan. Kelemahan dari model ini adalah :

1) Sangat bergantung pada kemampuan siswa dalam memahami materi sehingga apa yang dikuasai hanya sedikit. Hal ini dapat dilihat dari soal yang dibuat siswa biasanya hanya seputar materi yang sudah dijelaskan atau seperti contoh soal yang telah diberikan.

2) Ketua kelompok yang tidak mampu menjelaskan dengan baik tentu menjadi penghambat bagi anggota lain untuk memahami materi sehingga diperlukan waktu yang tidak sedikit untuk siswa mendiskusikan materi pembelajaran.

3) Tidak ada kuis individu maupun pengahargaan kelompok sehingga siswa saat berkelompok kurang termotivasi untuk bekerja sama. Tapi tidak menutup kemungkinan bagi guru untuk menambahkan pemberian kuis individu dan penghargaan kelompok

4) Memerlukan waktu yang panjang

5) Siswa yang nakal cenderung untuk berbuat onar

6) Kelas sering kali gaduh karena kelompok dibuat oleh siswa. Kelemahan dalam penggunaan model ini dapat ditutupi dengan cara : a. Guru menerankan terlebih b. dahulu materi yang akan didemonstrasikan secara singkat dan jelas disertai dengan aplikasinya. c. Mengoptimalisasi waktu dengan cara member batasan dalam pembuatan kelompok dan 
pembuatan pertanyaan. 6 d. Guru ikut serta dalam pembuatan kelompok sehingga kegaduhan bisa diatasi. e. Memisahkan group siswa yang dianggap sering dianggap sering membuat gaduh dalam kelompok yang berbeda. f. Tapi tidak menutup kemungkinan bagi guru untuk menambahkan pemberian kuis individu dan penghargaan kelompok.

\subsection{Daur hidup makhluk hidup}

\section{a. Pengertian Daur hidup hewan}

Daur hidup hewan adalah segala sesuatu yang berasal dari alam. Daur hidup hewan digunakan oleh manusia untuk memenuhi kebutuhan hidup dan kesejahteraannya. Menurut Fauzi (2004:6) menyatakan bahwa daur hidup hewan seperti air, udara, lahan, minyak, ikan, hutan, dan lain-lain merupakan sumber daya yang esensial bagi kelangsungan hidup manusia. Hilangnya atau berkurangnya ketersediaan sumber daya tersebut akan berdampak sangat besar bagi kelangsungan hidup umat manusia di muka bumi ini. Tanpa udara dan air misalnya, manusia tidak dapat hidup. Demikian pula daur hidup hewan yang lain seperti hutan, ikan dan lainnya merupakan sumber daya yang tidak saja mencukupi kebutuhan hidup manusia, namun juga memberikan kontribusi yang cukup besar bagi kesejahteraan suatu bangsa. Pengelolaan daur hidup hewan yang baik akan meningkatkan kesejahteraan umat manusia, dan sebaliknya pengelolaan daur hidup hewan yang tidak baik akan berdampak buruk.

Setelah menetas, hewan akan berkembang menjadi organisme dewasa. Perkembangan pasca lahir tersebut terjadi secara langsung dan tidak langsung. Yang dimaksud dengan perkembangan langsung adalah perkembangan pasca lahir tanpa melalui stadium larva. Perkembangan secara langsung ini melibatkan semacam perpanjangan perioda pertumbuhan yang mungkin berlangsung dengan lancar dan cepat sekali. Selama perioda ini, pada umumnya berlangsung pula perubahan-perubahan proporsi tubuh, serta maturasi gonad yang terjadi secara bertahap, dan awal perilaku berkembang biak. Hewan-hewan yang melaksanakan perkembangan secara langsung antara lain dari kelompok mamalia dan aves. Sebaliknya, yang dimaksud dengan perkembangan pasca lahir yang melalui satu atau lebih tadium larva, sebelum mencapai keadaan dewasanya. (Lukman, 2009: 42)

\section{b. Macam-macam Daur hidup hewan}

Seluruh tahapan perubahan yang dialami mahkluk hidup selama hidupnya disebut daur hidup. Anak katak yang baru menetas amat berbeda dengan induknya. Bentuk anak katak itu seperti ikan teri. Anak katak yang menetas disebut kecebong. Kecebong tumbuh dan mengalami 
tahap perubahaan bentuk menjadi katak dewasa. Tahap perubahan bentuk yang sangat berbeda yang dialami hewan sejak menetas sampai menjadi hewan dewasa disebut metamorphosis.

\section{c. Daur Hidup Tanpa Metamorfosis}

1. Daur Hidup Ayam

Ayam menghasilkan anak dengan cara bertelur. Telur ayam perlu dierami kira-kira 21 hari agar dapat menetas. Setelah pertumbuhan bakal anak ayam didalam telur sempurna, telur menetas menjadi anak ayam, setelah dewasa, ayam berkembang biak dan menghasilkan telur. Dari telur ini, daur hidup ayam yang baru dimulai kembali

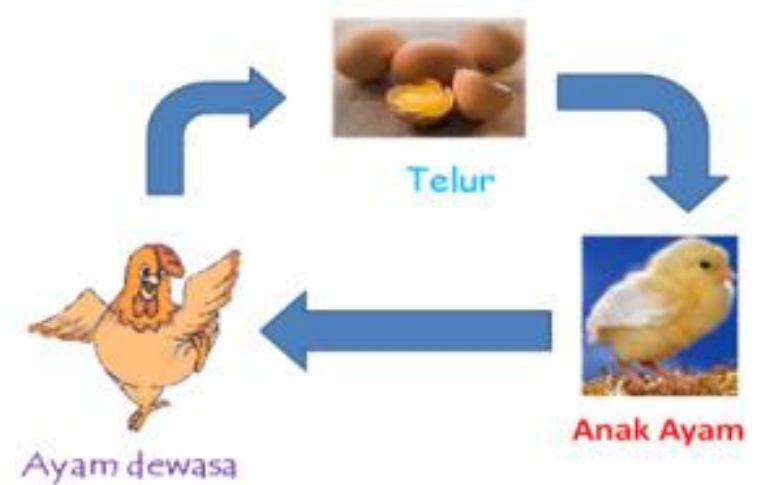

Gambar 2.1 Daur hidup ayam

(Sumber: Syuri, 2011)

\section{Daur Hidup Kucing}

Kucing menghasilkan anak dengan cara beranak (melahirkan) sebelum anaknya lahir, kucing dewasa mengalami masa mengandung selama kira-kira tiga bulan. Setelah itu lahirlah anak kucing yang belum dapat bergerak dengan lincah. Anak kucing ini belum dapat makan sendiri. Dia menyusu ke induknya setelah umurnya dari sebulan, anak kucing baru dapat memakan makanan lain.

Kucing yang garis keturunannya tercatat secara resmi sebagai kucing ras atau galur murni, seperti persia, siam, manx, dan sphinx, biasanya dibiakkan di tempat pemeliharaan hewan resmi dengan sanitasi yang baik. Akan tetapi, jumlah kucing ras hanyalah 1\% dari seluruh kucing di dunia, sisanya adalah kucing dengan keturunan campuran seperti kucing liar atau kucing kampung yang diperlihara manusia secara sederhana atau hidup berkeliaran di pemukiman. (Nurcahyo. dkk, 2014: 147) 


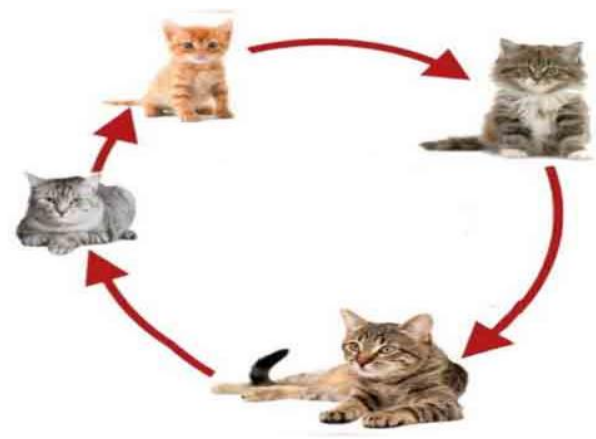

Gambar 2.2 Daur hidup kucing

(Sumber: Syuri, 2011)

\section{Daur Hidup Kambing}

Kambing adalah hewan menyusui, oleh karena itu kambing termasuk hewan mamalia. Contoh hewan lain yang termasuk hewan menyusui adalah sapi, kerbau, domba, kucing. Kambing berkembang biak dengan cara melahirkan anak. Kambing betina dewasa melahirkan anak anaknya. Kambing yang baru lahir berukuran kecil, bayi kambing menyusu pada induknya. Setelah beberapa minggu kambing bertambah besar. Kambing remaja mulai mencari makanan sendiri berupa rumput dan tumbuh-tumbuhan. Setelah beberpa bulan kambing remaja tumbuh menjadi kambing dewasa. Kambing dewasa bisa melakukan perkawinan sehingga bisa menghasilkan keturunan kembali, dan seterusnya daur hidup kambing.

Kambing merupakan salah satu jenis ternak ruminansia kecil yang banyak dipelihara oleh masyarakat baik secara tradisional maupun untuk kepentingan agribisnis. Selain untuk kepentingan produksi daging, ternak kambing juga sebagai sumber penghasil susu dan kulit. Hal ini karena kemampuan beradaptasi dan mempertahankan dirinya di lingkungan yang sangat ekstrim sehingga masyarakat banyak mengusahakan ternak kambing. (Ismail, 2009: 180) 

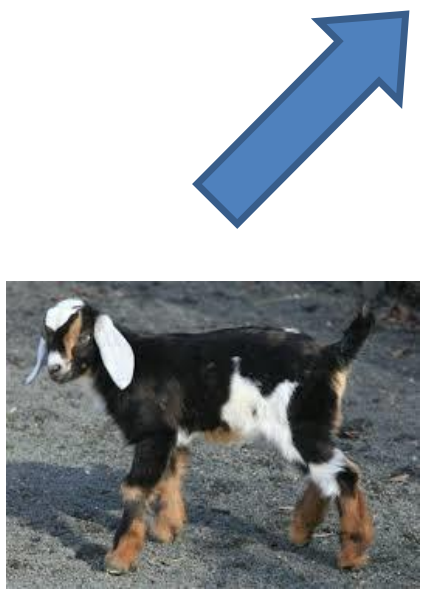

Kambing remaja/muda
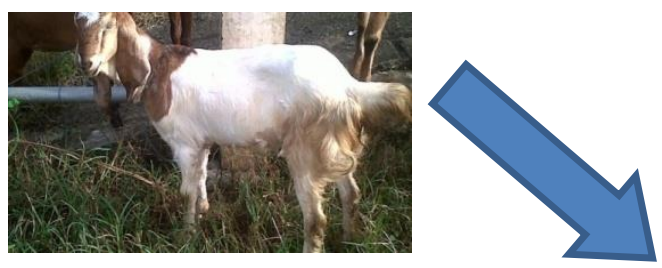

Kambing dewasa
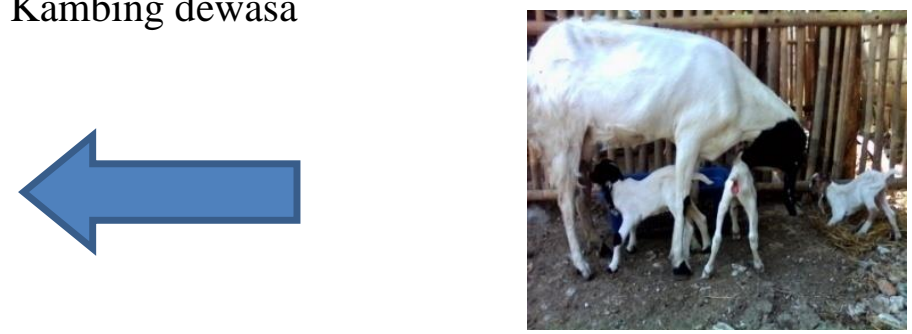

Kambing dewasa melahirkan

anak kambing

Gambar 2.3 Daur hidup kambing

(Sumber: Syuri, 2011)

\section{Daur Hidup paus}

Satu kelompok mamalia yang hidup di laut. Paus termasuk hewan terbesar yang pernah hidup di dunia Panjangnya dapat mencapai 30 meter dan berarti sampai 136 ton, lebih besar dari dinosaurus. Beberapa jenis paus memiliki gigi seragam, sedangkan beberapa lainnya tidak memiliki gigi, tetapi memiliki keping-keping tulang seperti sisir (baleen, Inggris) yang merupakan modifikasi selaput lendir. Secara sepintas, bentuk badannya mirip bangsa ikan. Bedanya, paus memiliki ujung ekor dengan posisi mendatar, sedangkan ujung ekor ikan berupa sirip tegak. Badan mamalia laut ini berbentuk torpedo dengan kedua kaki depan berubah menjadi sirip dada, sedangkan kaki belakang tidak ada, tetapi biasanya berubah bentuk menjadi sirip di bagian atas punggung.

Pada kepalanya terdapat rambut yang tumbuhnya tersebar dan jarang. Binatang air ini tidak memiliki kelenjar keringat, namun di bawah kulitnya ada lapisan serabut berisi lemak dan minyak yang dapat membantu pengaturan panas tubuh. Paus tidak bersisik dan berinsang. Binatang ini bernapas dengan paru-paru melalui lubang hembusan yang dimilikinya. Paus yang bergigi mempunyai sebuah lubang hembusan, sedangkan paus dengan keping-keping tulang sisir mempunyai dua buah lubang hembusan. Lubang ini mempunyai semacam klep yang dapat menutup jika paus menyelam. Mamalia ini juga memiliki kelenjar yang eks- kretanya dikeluarkan melalui mata; ekskreta ini berguna untuk melindungi mata terhadap iritasi air laut. 


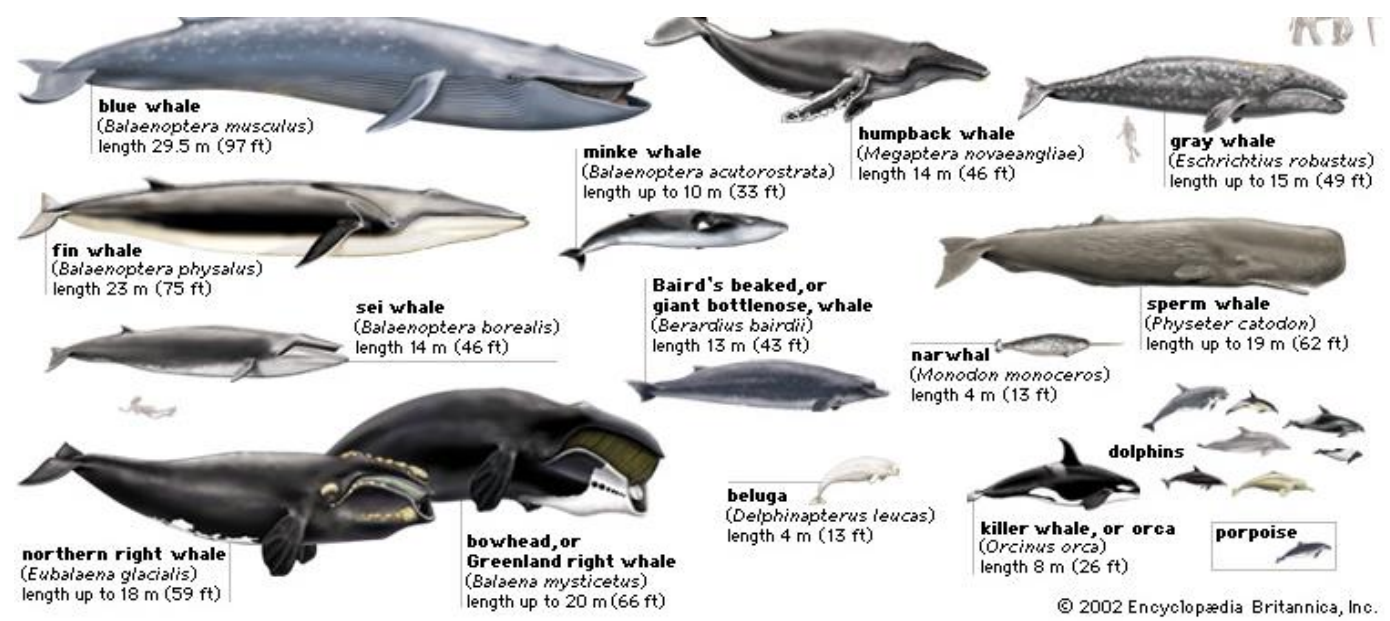

Gambar 2.4 Daur hidup paus

(Sumber: Syuri, 2011)

\section{d. Daur Hidup Dengan Metamorfosis}

Berdasarkan perubahan bentuk tubuh hewan, metamorphosis dibagi menjadi dua golongan sebagai berikut:

1. Metamorfosis sempurna (lengkap)

Metamorfosis sempurna dialami hewan yang saat lahir tidak terlalu berbeda bentuknya dengan hewan dewasa. Metamorfosis tidak sempurna antara lain terjadi pada kupu-kupu, lalat, nyamuk, dan katak.

a. Daur Hidup kupu-kupu

Daur hidup kupu-kupu di mulai di telur kupu-kupu biasanya berbeda pada permukaan daur telur menetas menjadi ulat. Ulat mempertahankan hidupnya dengan makanan dedaunan, selama berhari-hari ulat makan akan tetapi, makin lama ulat makan makin sedikit. Demikian pula gerakan ulat makin lama makin lambat. Akhirnya ulat berhenti makan dan tampak tidak bergerak. Walaupun tidak makan dan tampak tidak bergerak, ulat itu tidak mati. 


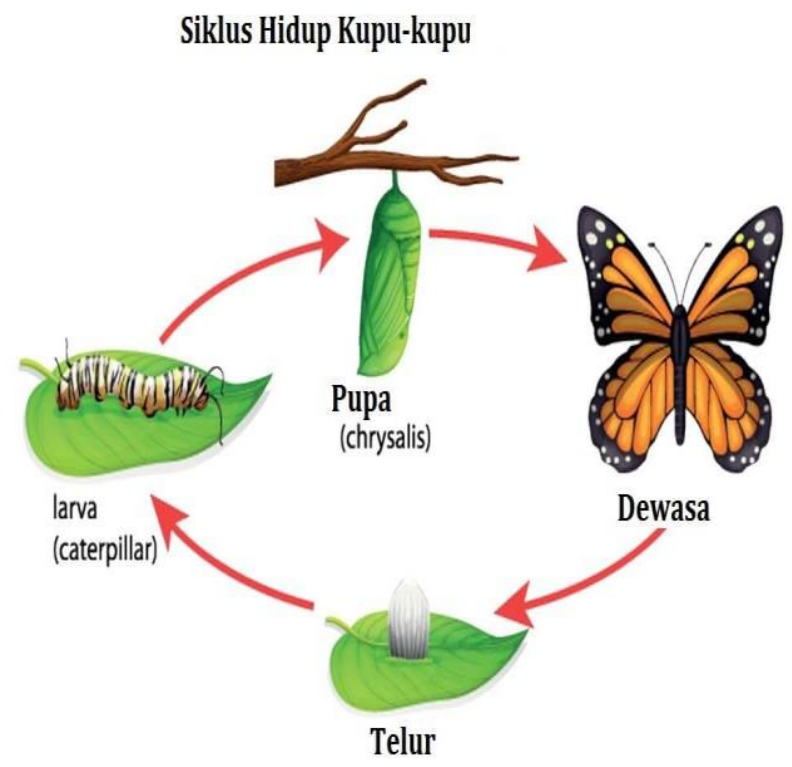

Gambar 2.5 Daur hidup kupu-kupu

(Sumber: Syuri, 2011)

b. Daur Hidup Nyamuk

Daur nyamuk dimulai dari telur. Telur nyamuk berada di air. Telur menetas menjadi jentik jentik (tempayak). Jentik jentik hidup dengan cara berenang di air. Jentik-jentik juga mendapatkan makanan di air. Jentik-jentik terus bergerak-gerak di air. Kemudian, jentik-jentik tumbuh dan berubah menjadi pupa. Pupa dapat berpindah karena dorongan gerakan air. Selanjutnya, pupa berubah menjadi nyamuk. Nyamuk terbang ke udara. Nyamuk dewasa akan kembali ke air untuk bertelur. Beberapa jenis nyamuk meletakkan telurnya di air kotor. Beberapa jenis nyamuk lain meletakkan telurnya di air jernih.

Tempat perkembangbiakan nyamuk disebut tempat perindukan, tempat ini merupakan bagian paling penting dalam siklus hidup nyamuk, karena melalui tempat perindukan ini kelangsungan siklus hidup nyamuk dapat berlangsung dengan normal. Nyamuk dapat mengganggu manusia dan binatang melalui gigitannya serta berperan sebagai vektor penyakit pada manusia dan binatang yang penyebabnya terdiri atas berbagai macam parasit dan virus. (Nadifah. dkk. 2016: 173) 


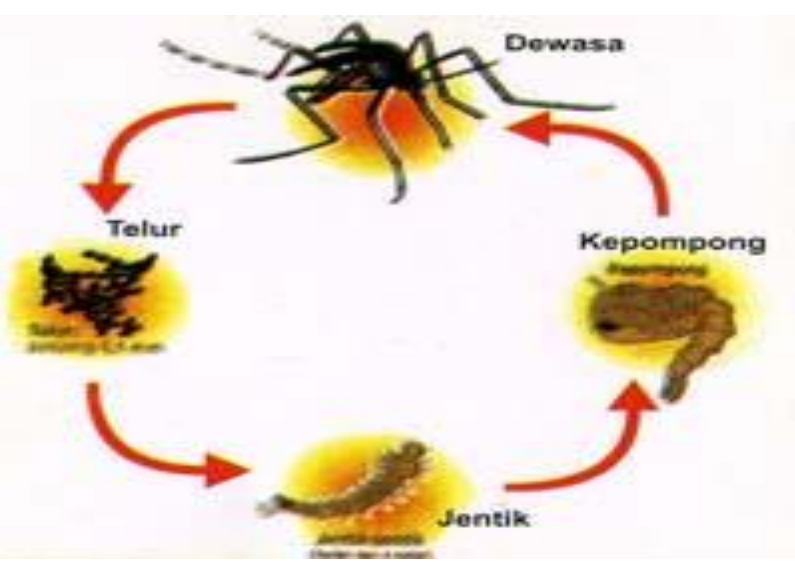

Gambar 2.6 Daur hidup nyamuk

(Sumber: Syuri, 2011)

c. Daur Hidup Lalat

Daur hidup lalat dimulai di telur. Telur lalat biasanya berada di tempat-tempat yang kotor, misalnya diatas timbunan sampah dan kotoran. Telur menetes menjadi belatung. Bentuk belatung seperti cacing kecil. Belatung bergerak dan menyerap mencari makanannya. Belatung paling banyak berada di tempat yang kotor dan debu. Kemudian belatung tumbuh dan berubah menjadi pupa. Pupa tidak bergerak, pupa menempel di tempat kotor.

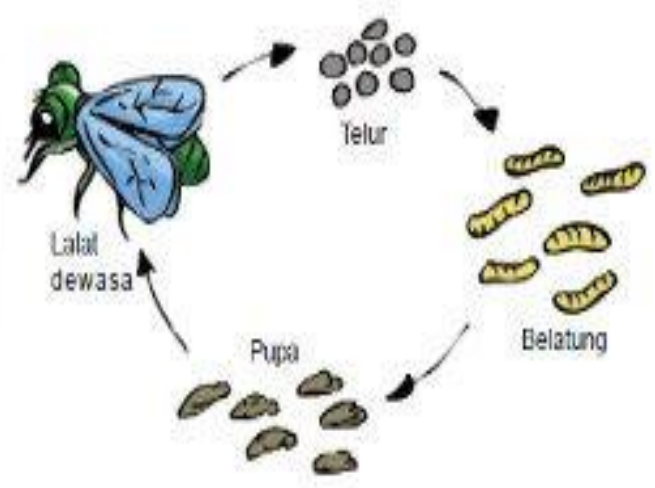

Gambar 2.7 Daur hidup lalat

(Sumber: Syuri, 2011)

\section{d. Daur Hidup Katak}

Katak adalah satu-satunya hewan bukan serangga yang mengalami metamorphosis. Kupu-kupu, nyamuk, lalat, dan kecoak termasuk golongan serangga. Katak merupakan hewan Amfibi, yaitu hewan yang hidup di air dan hidup di darat. Sepanjang hidupnya hidup di dua alam. Katak tidak dapat bertahan hidup jika tinggal di air saja atau di darat saja. 
Daur hidup katak dimulai dati telur. Telur katak berada di air. Telur menetes menjadi kecebong (berudu). Bentuk kecebong seperti ikan teri. Kecebong hidup dan umbuh dalam air. Kecebong bernapas dengan insang. Kemudian. Pada kecebong tumbuh sepasang kaki belakang dan disusul sepasang kaki depan. Kecebong berubah menjadi katak muda. Akhirnya ekor katak hilang.

Katak muda berubah menjadi katak dewasa yang tidak berekor. Katak dewasa bernapas dengan paru-paru dan kulit. Katak dewasa hidup di air dan di darat. Katak dewasa bertelur didalam air dan di darat. Katak dewasa bertelur di dalam air. Dari sini, mulailah telur katak menjalani daur hidupnya.

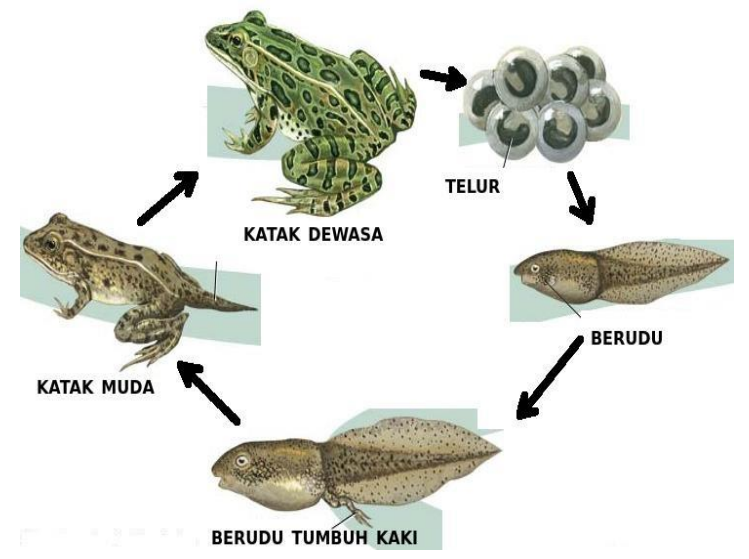

Gambar 2.8 Daur hidup katak

(Sumber: Syuri, 2011)

2. Metamorfosis tidak sempurna (tidak lengkap)

Metamorfosis tidak sempurna dialami hewan yang saat lahir terlalu berbeda dengan hewan dewasa. Metamorfosis tidaksempurna terjadi pada kecoa (lipas) dan belalang.

\section{a. Daur Hidup Kecoak}

Daur hidup kecoak (lipas) dimulai dari telur-telur kecoak menetes menjadi lipas muda. Bentuk kecoak muda mirip dengan kecoak biasa. Bedanya, kecoak tidak bersayap. Kecok muda tumbuh dan berubah menjadi kecoak dewasa. Kecoak tidak melalui tanpa pupa. Oleh karena itu, perubahan atau mertamorfosis kecoak merupakan mertamorfosis tidak sempurna (tidak lengkap). 


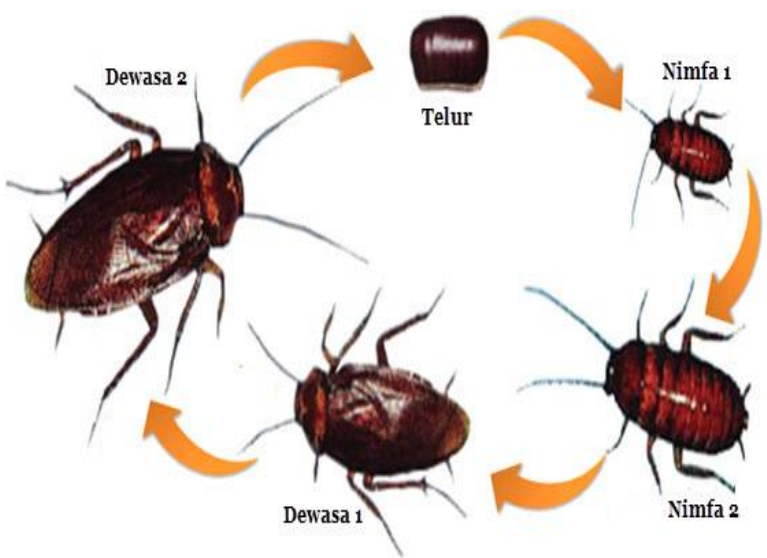

Gambar 2.9 Daur hidup kecoa

(Sumber: Syuri, 2011)

\section{b. Daur Hidup Belalang}

Belalang adalah serangga yang sering menjadi hama bagi tanaman para petani. Sifatnya yang rakus membuat daun-daun tanaman habis dimakannya. Kendati begitu, ia juga memiliki peran penting dalam menjaga keseimbangan ekosistem, terutama ekosistem sawah.

Metamorfosis belalang tergolong jenis metamorfosis tidak sempurna karena tidak mengalami fase kepompong atau pupa. Metamorfosis belalang hanya melalui 3 tahapan utama, yaitu fase telur, fase nimfa, dan fase belalang dewasa. Di artikel kali ini kita akan membahas ketiga tahapan metamorfosis belalang tersebut secara lengkap beserta gambar dan penjelasannya. Metamorfosis belalang mengikuti urutan tahapan mulai dari fase telur, nimfa, dan fase belalang dewasa. Skema tahapan proses metamorfosis tidak sempurna pada belalang tersebut dijelaskan seperti pada gambar di bawah ini.

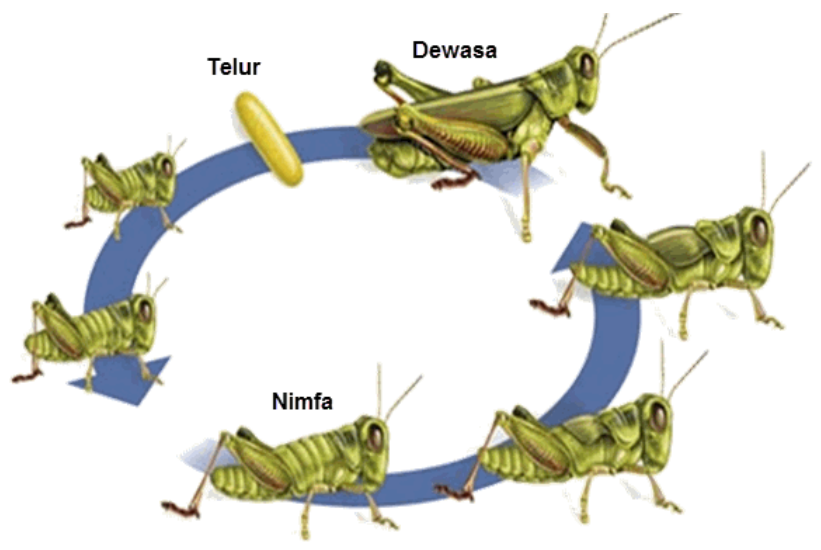

Gambar 2.10 Daur hidup belalang

(Sumber: Syuri, 2011) 


\section{c. Daur Hidup Lebah}

Lebah madu dan lebah secara umum termasuk contoh serangga yang mengalami metamorfosis sempurna dalam daur hidupnya. Metamorfosis lebah dikatakan demikian karena ia mengalami 4 tahapan metamorfosis, yaitu tahapan telur, tahapan larva, tahapan pupa, dan tahapan imago atau lebah dewasa. Di artikel ini, saya akan mengulas tentang bagaimana proses metamorfosis lebah tersebut dari setiap tahapannya lengkap dengan gambar dan penjelasannya.

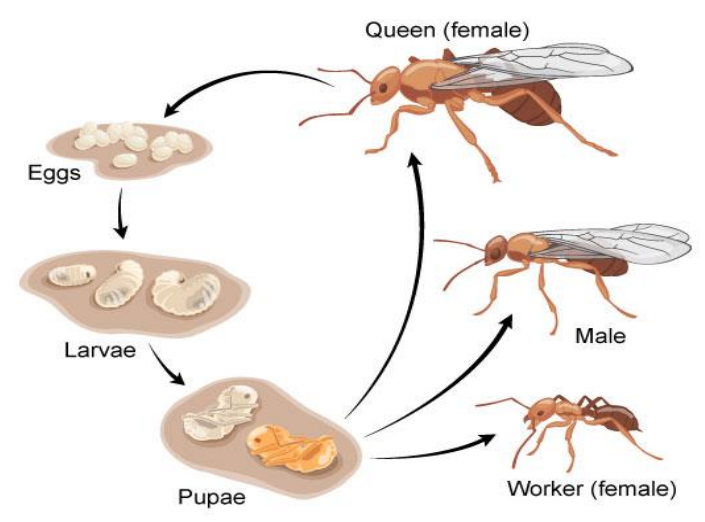

Gambar 2.11 Daur hidup lebah

(Sumber: Syuri, 2011)

Metamorfosis lebah melalui 4 tahapan, yaitu telur, larva, pupa, dan dewasa. Total waktu yang dibutuhkan untuk menyelesaikan keempat tahapan metamorfosis lebah tersebut bervariasi tergantung dari kasta lebahnya. Seperti diketahui, dalam kerajaan lebah terdapat pembagian 3 kasta, yaitu kasta lebah pekerja membutuhkan waktu sekitar 21 hari, kasta lebah prajurit membutuhkan waktu 24 hari, sementara kasta lebah ratu membutuhkan waktu hanya 16 hari untuk menyelesaikan 1 siklus metamorfosisnya.

\subsection{Memelihara Hewan Peliharaan}

Cara memelihara hewan yang benar adalah :

1. Memberi Makanan yang Sehat

Seperti manusia, hewan juga membutuhkan makanan yang cukup agar hidup sehat, misalnya kucing dan anjing. Kambing dan kelinci memakan daun-daunan. Ayam dapat memakan berbagai jenis makanan. Burung memakan jagung, semut, ulat atau buah-buahan.

2. Berprilaku hidup sehat 
Selain hewan peliharaan itu sendiri semua masyarakat yang memilki hewan peliharaan wajib melakukan pola hidup yang sehat. Karena jika dimulai dari pemilik hewan peliharaan yang melakukan pola hidup sehat maka secara tidak langsung hewan pelihaaraannya pun akan sehat. Pola hidup sehat yang harus dilakukan oleh pemilik hewan peliharaan adalah dengan menjaga kebersihan lingkungan, baik kandang hewan peliharaan, rumah maupun halaman. Pemilik hewan peliharaan harus menjaga kebersihan pribadi dengan cara mencuci tangan dengan mnggunakan sabun antiseptik serta mengganti pakaian setelah melakukan kontak langsung dengan hewan peliharaan. Dengan menempatkan hewan peliharaan dalam kandang tersendiri, dapat mengurangi tingkat penularan penyakit zoonosis. Pemilik hewan peliharaan harus memiliki kandang yang cukup ventilasi untuk hewan peliharaannya sehingga sirkulasi udara dapat berjalan dengan lancar. Selain itu meningkatkan pengetahuan mengenai penyakit hewan dan mengajarkannya kepada seluruh anggota keluarga merupakan salah satu cara pemilik hewan peliharaan berprilaku hidup sehat.

\section{Ciri-ciri hewan peliharaan yang sehat}

Kesehatan hewan merupakan hal yang wajib diperhatikan bagi semua pemilik hewan peliharaan. Menurut Yuliarti (2007) berpendapat bahwa: Ada beberapa ciri-ciri hewan peliharaan yang sehat yaitu hewan peliharaan yang memiliki mata jernih dan bersih serta tidak terdapat perubahan lain. Hewan peliharaan dikatakan sehat jika hewan tersebut tidak memiliki luka ditubuhnya dan gigi mamalia bersih (tidak berlubang dan tidak memiliki karang gigi). Jika hewan tersebut memiliki bulu, contohnya anjing dan kucing, hewan tersebut dikatakan sehat jika memiliki bulu yang lebat, rapih dan tertata halus serta tidak 7 terdapat kutu, jamur ataupun parasite. Dan yang terakhir, yaitu selera nafsu makanpun dapat terlihat sehat atau tidaknya hewan peliharaan tersebut. 


\section{BAB 3. METODE PENELITIAN}

\subsection{Pendekatan dan Jenis Penelitian}

Pendekatan yang digunakan dalam penelitian ini adalah pendekatan kualitatif. Aqib (2009:15) mengemukakan bahwa "pendekatan kualitatif adalah penelitian yang didasarkan secara cermat, mendalam dan rinci sehingga dapat mengumpulkan data yang sangat lengkap dan dapat menghasilkan informasi yang menunjukkan kualitas sesuatu". Jenis penelitian yang digunakan adalah penelitian tindakan kelas (Classroom Action Research). Menurut Arikunto (2010: 2) "penelitian tindakan kelas (Classroom Action Research) yaitu penelitian yang dilakukan guru ke kelas atau di sekolah tempat dia mengajar dengan penekanan pada penyempurnaan atau peningkatan proses dan praksis pembelajaran. Tujuan penelitian tindakan kelas adalah mengetahui dampak dari suatu perlakuan, yaitu mencoba sesuatu, lalu dicermati akibat dari perilaku tersebut.

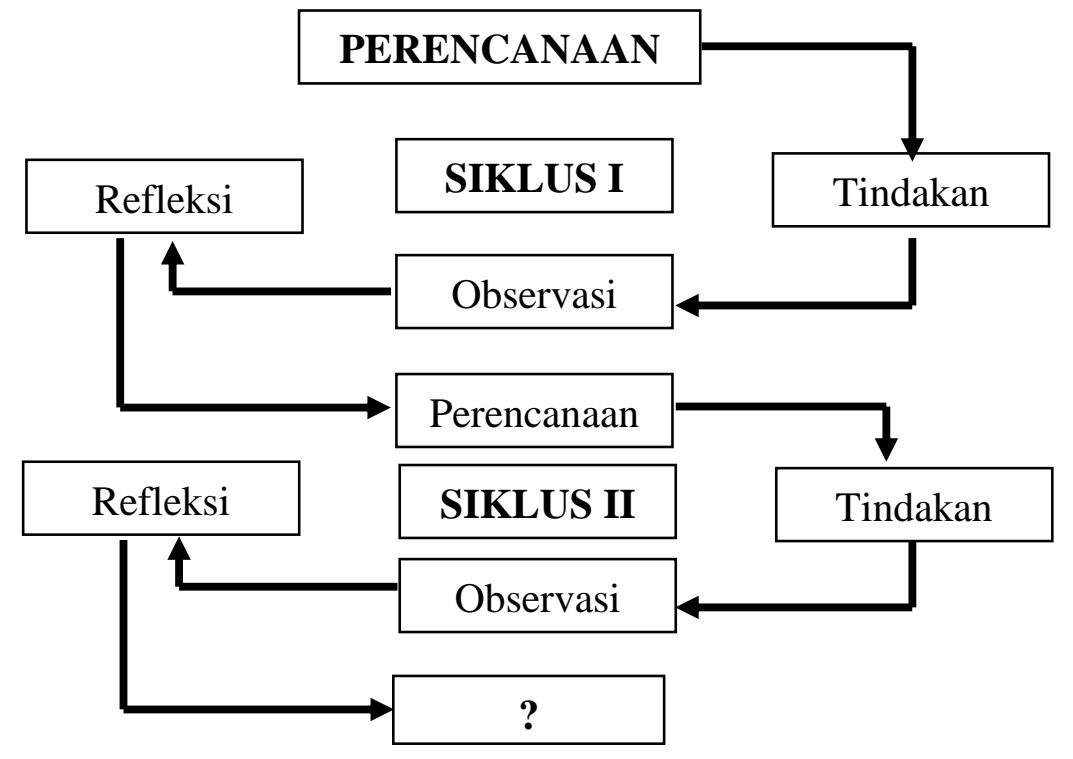

Gambar 3.1. Siklus Rancangan Penelitian Tindakan Kelas (PTK)

Sumber: Arikunto, dkk (2010:16) 


\subsection{Kehadiran Peneliti}

Sesuai dengan pendekatan dan jenis penelitian yang digunakan dalam penelitian ini, makam kehadiran peneliti sangat dibutuhkan. Hal ini dikarenakan peneliti bertindak sebagai instrument utama dan pemberi tindakan. Pada saat penelitian, peneliti dibantu oleh duan orang pengamat yang akan mengamati pelaksanaan tindakan. Peneliti juga bertindak sebagai pewawancara kepada subjek wawancara (respon) dengan berpedoman pada hasil tes. Dalam pelaksanaan kegiatan penelitian di bantu oleh dua orang pengamat untuk mengamati keseluruhan pembelajaran.

\subsection{Lokasi dan Waktu Penelitian}

Lokasi penelitian ini adalah di Kelas IV SD Negeri 3 Bireuen jumlah populasi sebanyak 31 siswa. Dilaksanakan pada semester ganjil tahun pelajaran 2017/2018.

\subsection{Data dan Sumber Data}

Data yang dikumpulkan dalam penelitian ini adalah sebagai berikut:

1. Nilai hasil belajar siswa setelah dilakukannya pembelajaran menggunakan model pembelajaran Snowbal Thowing. Soal yang diberikan pada akhir siklus dengan jumlah soal 20 item soal untuk pilihan ganda dan 5 soal essay.

2. Hasil observasi diperoleh dari penilaian 2 orang pengamat melalui mengisi lembar observasi aktifitas peneliti dan siswa. Observasi dilakukan adalah untuk mengukur proses pembelajaran yang dilaksanakan peneliti terhadap siswa kelas IV SD Negeri 3 Bireuen.

3. Data respon siswa berupa pemberian lembar angket respon siswa yang berisi 15 item pernyataan dengan kriteria jawaban 4.

4. Sumber data dalam penelitian ini adalah siswa kelas IV SD Negeri 3 Bireuen.

\subsection{Teknik Pengumpulan Data}

Metode yang digunakan dalam pengumpulan data penelitian ini adalah sebagai berikut:

1. Tes

Tes adalah alat ukur yang digunakan untuk menentukan taraf keberhasilan dalam pelaksanaan proses belajar mengajar disekolah. Tes yang diberikan berupa tes hasil belajar siswa berisikan soal dalam bentuk pilihan ganda yang berjumlah soal 20 item soal dan 5 soal essay.

2. Observasi 
Observasi dilakukan untuk mengamati aktivitas guru dan siswa selama kegiatan proses belajar mengajar dengan menggunakan model pembelajaran kooperatif tipe Snowbal Thowing berlangsung.

\section{Angket}

Angket merupakan alat untuk mengumpulkan data berupa peryataan yang dismpaikan kepada responden untuk dijawab dan diberikan tanggapan secara tertulis terhadap pembelajaran yang dilaksanakan. Angket respon siswa diberikan setelah proses belajar mengajar berlansung.

\subsection{Pengecekan Keabsahan Data}

Penelitian kualitatif harus mengungkap kebenaran yang objektif. Karena itu keabsahan data dalam sebuah penelitian kualitatif sangat penting. Melalui keabsahan data kredibilitas (kepercayaan) penelitian kualitatif dapat tercapai. Dalam penelitian ini untuk mendapatkan keabsahan data dilakukan dengan triangulasi. Adapun triangulasi adalah teknik pemeriksaan keabsahan data yang memanfaatkan sesuatu yang lain di luar data itu untuk keperluan pengecekan atau sebagai pembanding terhadap data itu (Moleong, 2005:330).

Dalam memenuhi keabsahan data penelitian ini dilakukan triangulasi dengan sumber. Menurut Patton, triangulasi dengan sumber berarti membandingkan dan mengecek balik derajat kepercayaan suatu informasi yang diperoleh melalui waktu dan alat yang berbeda dalam penelitian kualitatif. Triangulasi dengan sumber yang dilaksanakan pada penelitian ini yaitu membandingkan hasil wawancara dengan isi dokumen yang berkaitan.

\subsection{Teknik Analisis Data}

Data yang diperoleh dalam penelitian ini meliputi data aktivitas guru, data aktivitas siswa, dan data hasil belajar siswa. Adapun teknik analisis untuk masing-masing data adalah sebagai berikut:

1. Ketuntasan Klasikal

Untuk mengetahui tingkat ketuntasan klasikal dihitung dengan menggunakan rumus sebagai berikut:

$$
\text { Daya Serap }=\frac{\text { Jumlah siswa yang tuntas }}{\text { Jumlah seluruh siswa }} \times 100 \%
$$


Berdasarkan petunjuk pelaksanaan proses belajar mengajar, seorang siswa dikatakan tuntas belajarnya (ketuntasan individual) jika proporsi benar siswa $\geq 75 \%$ dan suatu kelas dikatakan tuntas belajar (ketuntasan klasikal).

\section{Analisis Data Aktivitas Guru dan Siswa}

Untuk mengetahui aktivitas guru dan siswa dalam kegiatan belajar mengajar melalui pembelajaran kreatif produktif dianalisis dengan menggunakan:

$$
S P_{1}=\frac{\text { jumlah skor }}{\text { skor maksimal }} \times 100 \% \quad S P_{2}=\frac{\text { jumlah skor }}{\text { skor maksimal }} \times 100 \%
$$

Sedangkan untuk menghitung rara-rata tiap pengamat adalah sebagai berikut:

$$
N R=\frac{S P_{1}+S P_{2}}{2}
$$

Taraf keberhasil proses pembelajaran:

$$
\begin{aligned}
& 90 \% \leq \mathrm{NR} \leq 100 \%: \text { Sangat baik } \\
& 80 \%<\mathrm{NR} \leq 90 \% \quad: \text { Baik } \\
& 70 \%<\mathrm{NR} \leq 80 \%
\end{aligned}
$$

\section{Respon Siswa}

Untuk mengetahui respon siswa dengan mempresentasikan jawaban dari angket yang diberikan kepada siswa dengan statistik deskriptif sebagai berikut:

$$
P=\frac{f}{n} \times 100 \%
$$

Dimana:

$P=$ Persentase yang dicari

$f=$ Frekuensi jawaban siswa

$n=$ jumlah siswa

\subsection{Tahap-tahap Penelitian}

1. Perencanaan kegiatan.

a. Menyiapkan tes

b. Membuat rencana pelaksanaan pembelajaran sesuai dengan materi yang diajarkan

c. Menyiapkan alat dan bahan yang diperlukan dalam pembelajaran 
d. Menyiapkan lembaran kerja siswa (LKS)

e. Menyiapkan tes akhir siklus

f. Menyusun lembar observasi untuk mengetahui bagaimana kondisi hasil dan proses belajar mengajar di Kelas IV SD Negeri 3 Bireuen.

g. Menyusun angket penelitian yang akan diberikan kepada siswa

2. Tindakan

a. Memotivasi siswa untuk belajar dengan memberikan beberapa pertanyaan.

b. Menyampaikan tujuan pembelajaran

c. Mengorganisasikan murid dalam kelompok kecil

d. Menentukan masalah yang akan diselidiki

e. Membimbing murid dalam belajar dan berkejasama memecahkan masalah.

f. Mempresentasikan hasil kerja didepan kelas.

g. Menyimpulkan hasil pembelajaran

\section{Observasi}

Observasi dilaksanakan pada proses pelaksanaan tindakan dengan menggunakan lembar observasi yang telah dipersiapkan. Adapun hal yang diobservasi adalah aktivitas guru dan siswa selama pembelajaran berlangsung.

4. Refleksi

Kegiatan penelitian pada tahap refleksi, yaitu menganalisis data-data yang diperoleh dari observasi, dengan maksud untuk melihat keseluruhan proses pelaksanaan tindakan dan hasil pemahaman siswa agar dapat diambil kesimpulan dalam merencanakan tindakan selanjutnya. Adapun kriteria keberhasil tindakan terdiri dari kriteria proses dan hasil. Kriteria proses adalah jika hasil observasi terhadap pembelajaran yang telah mencapai $80 \%$, sedangkan kriteria hasil adalah jika skor perolehan siswa hasil tes telah mencapai $\geq 65$ sebanyak $75 \%$.

Apabila proses pembelajaran sudah tercapai tetapi hasil pelaksanaan pembelajaran belum tercapai, maka peneliti masuk ke tindakan II dan merevisi kelemahan yang terdapat pada tindakan I. sebaliknya jika kriteria hasil tercapai tetapi pembelajaran belum tercapai, peneliti juga harus masukkan 


\section{BAB 4. HASIL PENELITIAN DAN PEMBAHASAN}

\subsection{Hasil Penelitian}

\subsubsection{Gambaran Penelitian}

Pelaksanaan penelitian ini berjumlah 2 pertemuan untuk siap siklusnya pada kelas IV, menyampaikan tujuan penelitian serta rencana yang akan dilaksanakan pada saat penelitian nantinya. Sebagai kelengkapan administrasi peneliti menyampaikan surat izin penelitian kepada kepala sekolah yang dituju. Kepala Sekolah menanggapi dengan baik keinginan peneliti, kemudian menyarankan untuk berdiskusi menetapkan jadwal pelaksanaan tes guru yang mengajar IPA di kelas IV, menentukan 2 orang pengamat yang akan mengamati jalannya penelitian yang dilaksanakan. Peneliti juga mengevaluasi bahan-bahan kelengkapan yang harus dipersiapkan dan menanyakan kepada guru apa saja yang harus disediakan agar proses pembelajaran berjalan dengan baik.

\subsubsection{Penelitian Siklus I}

Rencana pelaksanaan siklusI diterapkan melalui beberapa langkah berikut ini.

\section{A. Perencanaan}

Pada tahap perencanaan diawali dengan kegiatan pengenalan model pembelajaran Snowball Throwingkepada kolaborator yaitu teman sejawat yang bertugas sebagai pengamat. Selanjutnya, bersama dengan kolaborator melakukan penyusunanlangkah-langkah pembelajaran dengan menerapkan Model pembelajaran Snowball Throwing. Hal yang perlu dipersiapkan sebagai berikut:

1. Menyiapkan RPP (Rencana Pelaksanaan Pembelajaran)

2. Peneliti menyiapkan materi yang disajikan

3. Media pembelajaran berupa gambar hewan

4. Menyiapkan lembar kerja siswa

5. Menyiapkan lembar observasi kegiatan guru dan siswa

6. Menyiapkan angket penelitian bagi siswa

7. Menyiapkan tes akhir siklus I untuk mengukur hasil belajar

\section{B. Pelaksanaan}

Pelaksanaan kegiatan belajar mengajar untuk siklus I dilaksanakan pada hariSelasa, 25 Juli 2017.di SD Negeri 3 Bireuen, dengan jumlah siswa sebanyak 31 siswa. Pertemuan yang dilaksanakan sebanyak1 kali pertemuan. 
Kegiatan awal, guru mengkondisikan kelas dengan mengabsensi,berdoa, dan lain-lain. Guru melakukan apersepsi:Apa yang kalian tahu tentang daur hidup, apakah manusia tergolong dalam makhluk hidup yang melakukan daur hidup. Guru menyampaikan tujuan pembelajaran dan langkah-langkah pembelajaran.

Pada tahap inti, guru membagi topik yang akan dipelajari.Guru meminta siswa untuk memilih topik yang akan dipelajari. Guru membentuk siswa dalam beberapa kelompok.Guru membagikan bahan bacaan untuk masing-masing kelompok.Guru meminta siswa mengerjakan bahan bacaan secara berkelompok. Guru menyuruh siswa melempar kertas yang berisi pertanyaan dari satu siswa ke siswa yang lain. Guru menyuruh kepada siswa yang memperoleh bola/ pertanyaan untuk menjawab secara bergantian kedepan kelas. Guru bersama-sama mengevaluasi (mengomentari, memberi kritik dan saran) terhadap penampilan dan materi laporan masing-masing kelompok. Guru memberikan penghargaan kepada kelompok yang telah tampil.

Pada Tahap akhir, guru dan siswa bersama-sama mengambil kesimpulan dari pembelajaran yang telah dilalui. Guru memberikan tes akhir yang dilaksanakan secara individu. Menutup pembelajaran dan memberikan salam.

\section{Observasi Siklus I}

Pada tahap pengamatan, kegiatan yang dilakukan adalah mengumpulkan data dari setiap kejadian yang sedang berlangsung dan mencatatnya dengan alat observasi tentang hal-hal yang diamati. Pada tahap pengamatan, yang menjadi objek pengamatan adalah guru dan siswa.

Pelaksanaan aktivitasi guru yang diamati oleh 2 orang pengamat pada aktivitas guru selama kegiatan pembelajaran pada materi daur hidup hewan menggunakan model pembelajaran Snowball Throwing dapat dilihat pada Tabel 4.1 berikut ini. 
Tabel 4.1 Hasil Aktivitas Guru Pengamat I dan Pengamat II pada Siklus I

\begin{tabular}{|c|c|c|c|c|c|c|c|c|}
\hline \multirow[t]{2}{*}{ No } & \multirow[t]{2}{*}{ Kegiatan } & \multicolumn{2}{|c|}{$\begin{array}{c}\text { Skor } \\
\text { Perolehan }\end{array}$} & \multirow{2}{*}{$\begin{array}{c}\text { SM } \\
\text { (skor } \\
\text { Maksimum) }\end{array}$} & \multicolumn{2}{|c|}{$\%$} & \multirow{2}{*}{$\begin{array}{c}\text { Rata- } \\
\text { rata }\end{array}$} & \multirow[t]{2}{*}{ Ket } \\
\hline & & $\mathbf{S P}_{1}$ & $\mathbf{S P}_{2}$ & & $\mathbf{P}_{1}$ & $\mathbf{P}_{2}$ & & \\
\hline 1 & Awal & 11 & 12 & 15 & 73,33 & 80 & $76,67 \%$ & Cukup \\
\hline 2 & Inti & 31 & 31 & 45 & 68,89 & 68,89 & $68,89 \%$ & Kurang \\
\hline \multirow[t]{3}{*}{3} & Akhir & 8 & 8 & 10 & 80 & 80 & $80 \%$ & Cukup \\
\hline & & & & & \multicolumn{2}{|c|}{ Jumlah } & 225,56 & \\
\hline & & & & & \multicolumn{2}{|c|}{ Rata-Rata } & $75,19 \%$ & Cukup \\
\hline
\end{tabular}

Pada Tabel 4.1 di atas terlihatbahwa aktivitas guru pada siklus I diperoleh 75,19\% pada ketegori baik, hal ini berarti pembelajaran yang dilaksanakan guru sudah membaik dan dapat membantu siswa dalam belajar, hanya saja ada beberapa hal yang masih terlaksana dengan baik, misalnya guru masih gugup saat menyampaikan materi, guru terlalu sibuk membaca buku dan menulis didepan kelas.

Pelaksanaan aktivitas siswa yang dilakukan oleh 2 orang pengamat pada aktivitas siswa selama kegiatan pembelajaran pada materi daur hidup hewan menggunakan model pembelajaran Snowball Throwing dapat dilihat pada Tabel 4.2 berikut ini.

Tabel 4.2 Hasil Aktivitas Siswa Pengamat I dan Pengamat II pada Siklus I

\begin{tabular}{|c|c|c|c|c|c|c|c|c|}
\hline \multirow{3}{*}{ No } & \multirow{3}{*}{ Kegiatan } & \multirow{2}{*}{\multicolumn{2}{|c|}{$\begin{array}{c}\text { Skor } \\
\text { Perolehan }\end{array}$}} & \multirow{3}{*}{$\begin{array}{c}\mathbf{S M} \\
\text { (Skor } \\
\text { Maksimum) }\end{array}$} & \multirow{2}{*}{\multicolumn{2}{|c|}{$\%$}} & \multirow{3}{*}{$\begin{array}{l}\text { Rata- } \\
\text { rata }\end{array}$} & \multirow{3}{*}{ Ket } \\
\hline & & & & & & & & \\
\hline & & $\mathbf{S P}_{1}$ & $\mathbf{S P}_{2}$ & & $\mathbf{P}_{1}$ & $\mathbf{P}_{2}$ & & \\
\hline 1 & Awal & 11 & 12 & 15 & 73,33 & 80 & $76,67 \%$ & Cukup \\
\hline 2 & Inti & 28 & 29 & 45 & 62,22 & 64,44 & $63,33 \%$ & Kurang \\
\hline \multirow[t]{3}{*}{3} & Akhir & 8 & 8 & 10 & 80 & 80 & $80 \%$ & Cukup \\
\hline & & & & & \multicolumn{2}{|c|}{ Jumlah } & 220 & \\
\hline & & & & & \multicolumn{2}{|c|}{ Rata-Rata } & $73,33 \%$ & Cukup \\
\hline
\end{tabular}

Dari Tabel 4.2 di atas terlihatbahwa aktivitas siswa pada siklus I diperoleh 73,33\% pada ketegori cukup, hal ini berarti pembelajaran yang dilaksanakan masih berjalan satu arah, masih 
banyak guru yang berbicara, tidak semua siswa berkerja pada saat melakukan diskusi, sisanya hanya duduk melihat, memperhatikan teman saja.

\section{Hasil Tes Siklus I}

Dari hasil tes yang diberikan pada akhir siklus pertama, maka hasil belajar dalam pembelajaran dengan menerapkan model pembelajaran Snowball Throwingpada materi daur hidup hewan masih rendah. Hal ini dapat dilihat dari Tabel 4.3 berikut ini.

Tabel 4.3Hasil belajar Pada Siklus I

\begin{tabular}{cccc}
\hline No. & Daya Serap & Jumlah Siswa & Persentase \\
\hline 1. & Tuntas & 20 & $64,52 \%$ \\
2. & Tidak tuntas & 11 & $35,48 \%$ \\
\hline & Jumlah & $\mathbf{3 1}$ & $\mathbf{1 0 0 \%}$ \\
\hline
\end{tabular}

Dari Tabel 4.3 menunjukkan bahwa hasil belajar pada siklus pertama pada pembelajaran menggunakanmodel pembelajaran Snowball Throwingmateri daur hidup hewanmasih belum membaik dan masih perlu dilakukan perbaikan. Analisis hasil belajar siklus pertama, terdapat bahwa dari 31 jumlah siswa hanya20 siswa yang tuntas dengan persentase sebesar 64,52\%. Hasil belajar pada siklus I sesuai dengantabel matriks ketuntasan belajar siswa siklus I. sehingga dapat dikatakan bahwa kegiatan belajar mengajar denganmodel pembelajaran Snowball Throwing masih belum memberikan dampak pada hasil belajar. Setelah dianalisis lebih lanjut, maka dapat dikatakan bahwa pembelajaran pada siklus Ibelum memadai dan perlu perbaikan pada siklus berikutnya.

\section{E. Refleksi}

Berdasarkan penelitian yang telah dilaksanakan pada siklus I diperoleh beberapa kelemahan yang timbul baik dari guru maupun dari siswa. Hasil refleksi ini didiskusikan dengan guru pengamat yaitu guru bidang studi dan teman sejawat. Dari hasil refleksi tersebut, guru dapat mencatat berbagai kekurangan yang perlu diperbaiki. Sehingga dapat dijadikan dasar dalam penyusunan rencana ulang.Dari tindakan yang diberikan oleh guru dapat dilihat dari kelemahan baik dari guru maupun dari siswa, antara lain:

1. Guru kurang dalam memotivasi siswa

2. Pertanyaan yang diajukan guru menyulitkan siswa 
3. Pembelajaran yang dilaksanakan masih kurang aktif masih banyak guru yang bekerja dari pada siswa.

4. Penjelasan materi terlalu singkat dan kurang detail, guru tidak memberi contoh yang mudah dipahami oleh siswa

5. Siswa saat melaksanakan diskusi masih merasa bingung karena guru tidak menyampaikan tatacara membuat pertanyaan.

6. Tidak semua siswa dapat bermau dalam belajar, masih ada saja siswa yang berkeliaran saat guru sedang menjelaskan dan saat diskusi berlangsung.

7. Hasil belajar masih rendah hal ini terlihat dari jumlah siswa yang tuntas hanya 20 orang siswa.

\subsubsection{Penelitian Siklus II}

Rencana pelaksanaan siklus ini diterapkan melalui beberapa langkah berikut ini.

\section{A. Perencanaan}

Pada tahap perencanaan diawali dengan kegiatan pengenalan model pembelajaran Snowball Throwing kepada kolaborator yaitu teman sejawat yang bertugas sebagai pengamat. Selanjutnya, bersama dengan kolaborator melakukan penyusunanlangkah-langkah pembelajaran dengan menerapkan model pembelajaran Snowball Throwing. Hal-hal yang perlu dipersiapkan adalah sebagai berikut:

1. Menyiapkan RPP (Rencana Pelaksanaan Pembelajaran)

2. Peneliti menyiapkan materi yang disajikan

3. Menyiapkan lembar kerja siswa

4. Menyiapkan lembar observasi kegiatan guru dan siswa

5. Menyiapkan angket penelitian bagi siswa

6. Menyiapkan tes akhir siklus II untuk mengukur hasil belajar

\section{B. Pelaksanaan}

Pelaksanaan kegiatan belajar mengajar untuk siklus II dilaksanakan pada hari Jum'at, 28 Juli 2017di SD Negeri 3 Bireuen, dengan jumlah siswa sebanyak 31 siswa. Pertemuan yang dilaksanakan sebanyak1 kali pertemuan.

Kegiatan awal, guru mengkondisikan kelas dengan mengabsensi,berdoa, dan lain-lain. Guru melakukan apersepsi:Apa yang kalian tahu tentang cara memeliihara hewan peliharaan. Guru menyampaikan tujuan pembelajaran dan langkah-langkah pembelajaran 
Pada tahap inti, guru membagi topik yang akan dipelajari.Guru meminta siswa untuk memilih topik yang akan dipelajari. Guru membentuk siswa dalam beberapa kelompok.Guru membagikan bahan bacaan untuk masing-masing kelompok.Guru meminta siswa mengerjakan bahan bacaan secara berkelompok. Guru menyuruh siswa melempar kertas yang berisi pertanyaan dari satu siswa ke siswa yang lain. Guru menyuruh kepada siswa yang memperoleh bola/ pertanyaan untuk menjawab secara bergantian kedepan kelas. Guru bersama-sama mengevaluasi (mengomentari, memberi kritik dan saran) terhadap penampilan dan materi laporan masing-masing kelompok. Guru memberikan penghargaan kepada kelompok yang telah tampil.

Pada Tahap akhir, guru dan siswa bersama-sama mengambil kesimpulan dari pembelajaran yang telah dilalui. Guru memberikan tes akhir yang dilaksanakan secara individu. Menutup pembelajaran dan memberikan salam.

\section{Observasi Siklus II}

Pada tahap pengamatan, kegiatan yang dilakukan adalah mengumpulkan data dari setiap kejadian yang sedang berlangsung dan mencatatnya dengan alat observasi tentang hal-hal yang diamati. Untuk guru, hal yang dilakukan oleh observer adalah mengamati dan mencatat setiap tindakan yang dilakukan guru dalam setiap siklus atau tindakan pembelajaran sesuai dengan fokus masalah. Dari hasil pengamatan tersebut dapat ditemukan berbagai kelemahan-kelemahan sehingga dapat ditindaklanjuti untuk diperbaiki pada siklus berikutnya.

Berdasarkan hasil aktivitas guru pada siklus II oleh 2 orang pengamat pada aktivitas guru pada materi materi daur hidup hewan menggunakan pembelajaran Snowball Throwing dapat dilihat pada Tabel 4.4 berikut ini.

Tabel 4.4 Hasil Aktivitas Guru Pengamat I dan Pengamat II pada Siklus II

\begin{tabular}{|c|c|c|c|c|c|c|c|c|}
\hline \multirow[t]{2}{*}{ No } & \multirow[t]{2}{*}{ Kegiatan } & \multicolumn{2}{|c|}{$\begin{array}{c}\text { Skor } \\
\text { Perolehan }\end{array}$} & \multirow{2}{*}{$\begin{array}{c}\text { SM } \\
\text { (Skor } \\
\text { Maksimum) }\end{array}$} & \multicolumn{2}{|c|}{$\%$} & \multirow{2}{*}{$\begin{array}{l}\text { Rata- } \\
\text { rata }\end{array}$} & \multirow[t]{2}{*}{ Ket } \\
\hline & & $\overline{S P_{1}}$ & $\mathrm{SP}_{2}$ & & $\overline{P_{1}}$ & $\overline{P_{2}}$ & & \\
\hline 1 & Awal & 14 & 15 & 15 & 93,33 & 100 & 96,67 & Sangat baik \\
\hline 2 & Inti & 39 & 39 & 45 & 86,67 & 86,67 & 86,67 & Baik \\
\hline \multirow[t]{3}{*}{3} & Akhir & 10 & 10 & 10 & 100 & 100 & 100 & Sangat baik \\
\hline & & & & & & Jumlah & 283,33 & \\
\hline & & & & & \multicolumn{2}{|c|}{ Rata-Rata } & 94,45 & Sangat Baik \\
\hline
\end{tabular}


Dari Tabel 4.4 di atas terlihatbahwa aktivitas guru diperoleh 94,45\% kategori sangat baik. Hal ini berarti proses pembelajaran yang dilaksanakan sudah lebih baik dari siklus I, kegiatan awal guru sudah dapat menyampaikan apersepsi dan motivasi secara baik dan dimengerti siswa, begitu juga saat penyampaian materi dan diskusi berlangsung, guru juga menyampaikan kesimpulan kepada siswa, dan melakukan tanya jawab diakhir pembelajaran. Berdasarkan hasil aktivitas siswa pada siklus II oleh 2 orang pengamat pada aktivitas siswa selama kegiatan pembelajaran pada materi daur hidup hewan menggunakan model pembelajaran Snowball Throwing dapat dilihat pada Tabel 4.5 berikut ini.

Tabel 4.5 Hasil Aktivitas Siswa Pengamat I dan Pengamat II pada Siklus II

\begin{tabular}{|c|c|c|c|c|c|c|c|c|}
\hline \multirow[t]{2}{*}{ No } & \multirow[t]{2}{*}{ Kegiatan } & \multicolumn{2}{|c|}{$\begin{array}{c}\text { Skor } \\
\text { Perolehan }\end{array}$} & \multirow{2}{*}{$\begin{array}{c}\text { SM } \\
\text { (Skor } \\
\text { Maksimum) }\end{array}$} & \multicolumn{2}{|c|}{$\%$} & \multirow{2}{*}{$\begin{array}{l}\text { Rata- } \\
\text { rata }\end{array}$} & \multirow[t]{2}{*}{ Ket } \\
\hline & & $\overline{\text { SP1 }_{1}}$ & $\overline{\mathbf{S P}_{2}}$ & & $\mathbf{P}_{1}$ & $\overline{\mathbf{P}_{2}}$ & & \\
\hline 1 & Awal & 14 & 15 & 15 & 93,33 & 100 & $96,67 \%$ & Sangat Baik \\
\hline 2 & Inti & 36 & 36 & 45 & 80 & 80 & $80 \%$ & Sangat baik \\
\hline \multirow[t]{3}{*}{3} & Akhir & 10 & 10 & 10 & 100 & 100 & $100 \%$ & Sangat baik \\
\hline & & & & & \multicolumn{2}{|c|}{ Jumlah } & 276,67 & \\
\hline & & & & & \multicolumn{2}{|c|}{ Rata-Rata } & $92,22 \%$ & Sangat Baik \\
\hline
\end{tabular}

Dari Tabel 4.5 di atas terlihatbahwa aktivitas siswa diperoleh 92,22\% kategori sangat baik. Hal ini berarti proses pembelajaran yang diikuti siswa dapat memotivasi dengan baik, siswa sudah berani lakukan tanya jawab, sudah berdiskusi dengan baik, serta presentasi yang dilaksanakanpun sudah sangat baik.

\section{Hasil Siklus II}

Berdasarkan hasil tes yang diberikan pada akhir siklus kedua, maka hasil belajar dalam pembelajaran dengan menerapkan model pembelajaran Snowball Throwing pada materi daur hidup hewansudah meningkat. Hal ini dapat dilihat dari Tabel 4.6 berikut ini. 
Tabel 4.6 Hasil belajar Pada Siklus kedua

\begin{tabular}{cccc}
\hline No. & Daya Serap & Jumlah Siswa & Persentase \\
\hline 1. & Tuntas & 27 & $87,10 \%$ \\
2. & Tidak tuntas & 4 & $12,90 \%$ \\
\hline & Jumlah & $\mathbf{3 1}$ & $\mathbf{1 0 0 \%}$ \\
\hline
\end{tabular}

Dari Tabel 4.6 menunjukkan bahwa analisis hasil belajar pada siklus kedua pembelajaran dengan menerapkan model pembelajaran Snowball Throwing pada materi daur hidup hewansudah meningkat dari sebelumnya. Analisis hasil belajar siklus kedua, terdapat bahwa dari 31 jumlah siswa hanya 27 siswa yang tuntas dengan persentase 87,10\%. Berdasarkan hasil penelitian yang telah dilaksanakan juga ada hasil yang memperoleh nilai dibawah ini KKM yang telah dilaksanakan guru. Mengacu pada hasil prolehan siswa dan kegiatan pembelajarandenganmodel pembelajaran Snowball Throwing telah sudah sangat meningkat dan tidak perlu dilaksanakan siklus berikutnya.

\section{F. Refleksi}

Refleksi bertujuan untuk melihat berbagai kekurangan yang timbul setelah guru melaksanakan tindakan. Hasil refleksi ini didiskusikan dengan guru pengamat yaitu guru bidang studi dan teman sejawat. Dari hasil refleksi tersebut, guru dapat mencatat berbagai kekurangan yang perlu diperbaiki. Sehingga dapat dijadikan dasar dalam penyusunan rencana ulang.Tindakan yang diberikan oleh guru dapat dilihat dari keberhasilan antara lain:

1. Kegiatan belajar mengajar berlangsung lancar

2. Model pembelajaran Snowball Throwing marupakan pembelajaran yang mengarahkan siswa untuk lebih terampilan dalam melaksanakan pembelajaran baik secara individual maupun secara kelompokan

3. Pembelajaran Model pembelajaran Snowball Throwing adalah pembelajaran yang menekankan pada pembelajaran dikelas yang dipadu dengan kreativitas guru dalam memaksimal setiap kemampuan siswa dalam menyelesaikan setiap persoalan yang diberikan guru.

4. Pembelajaran Model pembelajaran Snowball Throwingmelibatkan peserta didik dalam proses pembelajaran yang aktif, kolaboratif, berpusat kepada peserta didik, yang 
mengembangkan kemampuan belajar mandiri yang diperlukan untuk menghadapi tantangan dalam kehidupan dan karier, dalam lingkungan yang bertambah kompleks sekarang ini

5. Hasil belajar tentang materi yang diajarkan meningkat

6. Kemampuan siswa mengkomunikasikan hasil kerja meningkat

\subsubsection{Analisis Respon Siswa}

Respon siswa terhadap pelaksanaan pembelajaran dengan menerapkan model pembelajaran Snowball Throwingdianalisis dengan menggunakan wawancara secara langsung dengan siswa. Diperoleh jawaban secara umum bahwa "senang" dan "tidak senang”. Respon siswa sudah baik pada pembelajaran yang dilaksanakan guru, siswa termotivasi melalui pembelajaran menggunkan model pembelajaran Snowball Throwing pada materi daur hidup hewan.

\subsubsection{Analisis Hasil Peningkatan}

\section{Peningkatan Hasil belajar}

Berdasarkan hasil penelitian yang sudah dilakukan dapat dilihat bahwa penerapan model pembelajaran Snowball Throwingdapat meningkatkan hasil belajar siswa. Secara terperinci dapat dilihat pada Tabel 4.7 berikut:

Tabel 4.7 Peningkatan hasil belajar siswa pada setiap siklus

\begin{tabular}{llccc}
\hline \multirow{2}{*}{ No } & \multirow{2}{*}{ Kriteria } & \multicolumn{3}{c}{ Peningkatan } \\
\cline { 3 - 5 } & & Siklus I & Siklus II & Peningkatan \\
\hline 1 & Tuntas & $64,52 \%$ & $87,10 \%$ & $22,58 \%$ \\
2 & Tidak Tuntas & $35,48 \%$ & $12,90 \%$ & \\
\hline
\end{tabular}

Berdasarkantabel di atas, maka diperoleh bahwa nilai rata-rata yang tuntas pada siklus I sebesar $64,52 \%$ menjadi $87,10 \%$ pada siklus II, hal ini berarti mengalami peningkatan sebesar 22,58\%. Dengan ini maka pembelajaran menggunakan model pembelajaran Snowball Throwing sudah dapat meningkatkan hasil belajar siswa .

Berdasarkan analisis data, maka dapat dilihat perubahan peningkatan hasil belajar pada setiap siklus. Perubahan hasil belajar tersebut menunjukkan adanya peningkatan hasil dalam pembelajaran denganmodel pembelajaran Snowball Throwing perbedaan peningkatan hasil belajar pada siklus pertama dan siklus kedua dapat dilihat pada Grafik 4.1berikut ini. 


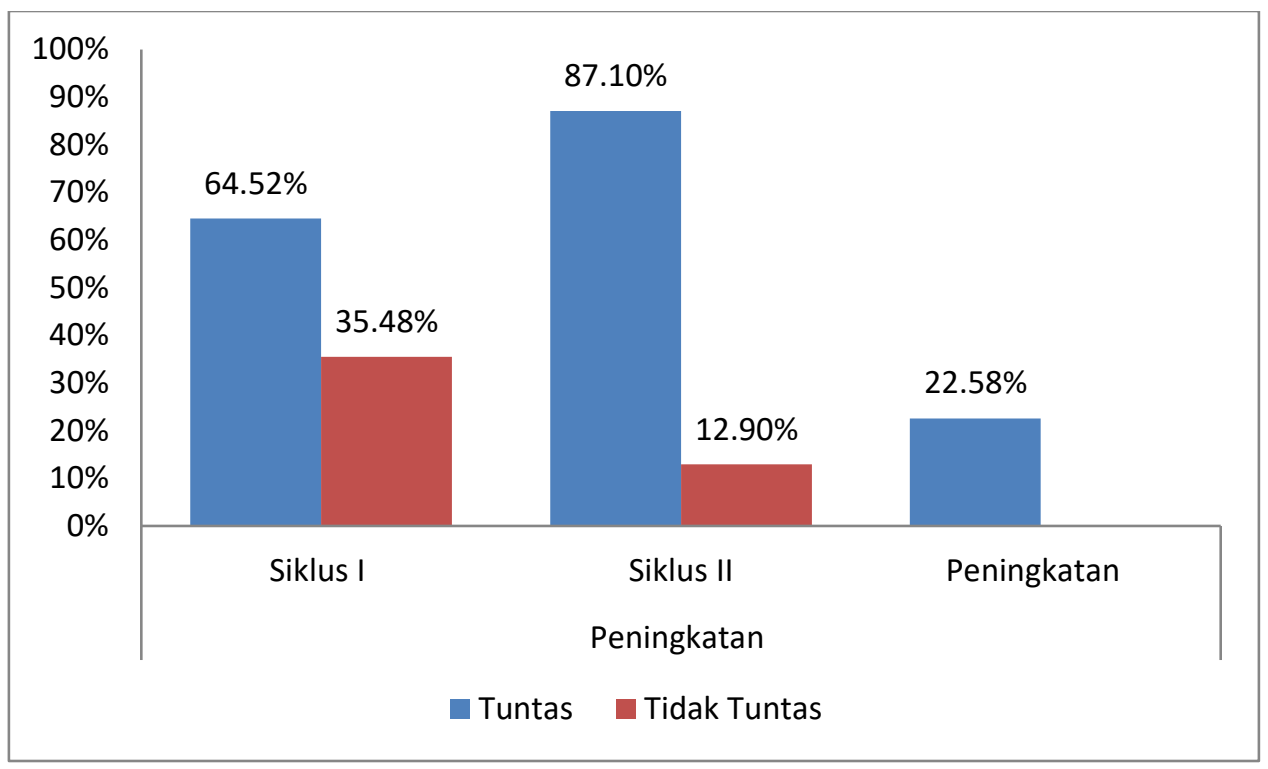

Grafik 4.1 Presentasepeningkatan hasil belajar pada setiap siklus

BerdasarkanGrafik 4.1 di atas, hasil ketuntas belajar siswa pada siklus I diperoleh 64,52\% dan siklus II diperoleh $87,10 \%$ mengalami peningkatan sebesar 22,58\%. Diperoleh bahwa proses pembelajaran yang dilaksanakan menggunakan model pembelajaran Snowball Throwing dapat meningkatkan hasil belajar siswa pada materi daur hidup hewan. Karena model pembelajaran Snowball Throwingdapat memberi siswa kesempatan untuk mengembangkan kemampuan berfikir karena diberi kesempatan untuk membuat soal dan diberikan kepada siswa lain, guru tidak terlalu repot membuat media karena siswa terjun langsung dalam praktek. Ketiga aspek yaitu aspek koknitif, afektif dan psikomotor dapat tercapai.

\section{Peningkatan Aktivitas Guru dan Siswa}

Hasil pengamatan oleh dua orang guru pengamat (observator) saat proses pembelajaran berlangsung, aktivitas guru dan aktivitas siswa sudah terlihat sangat baik. Secara ringkas hasil persentasenya dapat dilihat pada Tabel 4.10 berikut:

Tabel 4.11 Hasil observasi terhadap aktivitas guru dan siswa kelas IVSMP Negeri 1 Makmur pada materi daur hidup hewan siklus I dan II

\begin{tabular}{clccc}
\hline No & Jenis Aktivitas & Siklus I & Siklus II & Peningkatan \\
\hline 1 & Aktivitas guru & $75,19 \%$ & $94,45 \%$ & $19,26 \%$ \\
2 & Aktivitas siswa & $73,33 \%$ & $92,22 \%$ & $18,89 \%$ \\
\hline
\end{tabular}


Berdasarkan tabel 4.11 terlihat bahwa aktivitas belajar mengajar antara guru dan siswa telah berlangsung dengan baik. Ini terlihat dari hasil observasi siklus I dan II mengalami peningkatan dari pihak guru pada siklus I persentase sebesar 75,19\% pada siklus II naik menjadi 94,45\% sehingga terjadi peningkatan dari siklus I ke siklus II adalah 19,26\%. Sedangkan dari pihak siswa pada siklus I73,33\% juga mengalami peningkatan pada siklus II menjadi 92,22\% sehingga terjadi peningkatan dari siklus I ke siklus II adalah 18,89\%. Karena dapat membuat suasana pembelajaran menjadi menyenagkan karena siswa seperti bermain dengan melempar bola kertas kepada siswa lain. Selain itu membuat siswa siap dengan berbagai kemungkinan karena siswa tidak tahu yang dibuat temannya seperti apa. Siswa terlibat aktif dalam pembelajaran.

Pada aktivitas guru dan siswa selama proses pembelajaran yang diterapkan menggunakan model pembelajaran Snowball Throwing pada materi materi daur hidup hewan dapat dilihat pada Grafik 4.2 berikut ini:

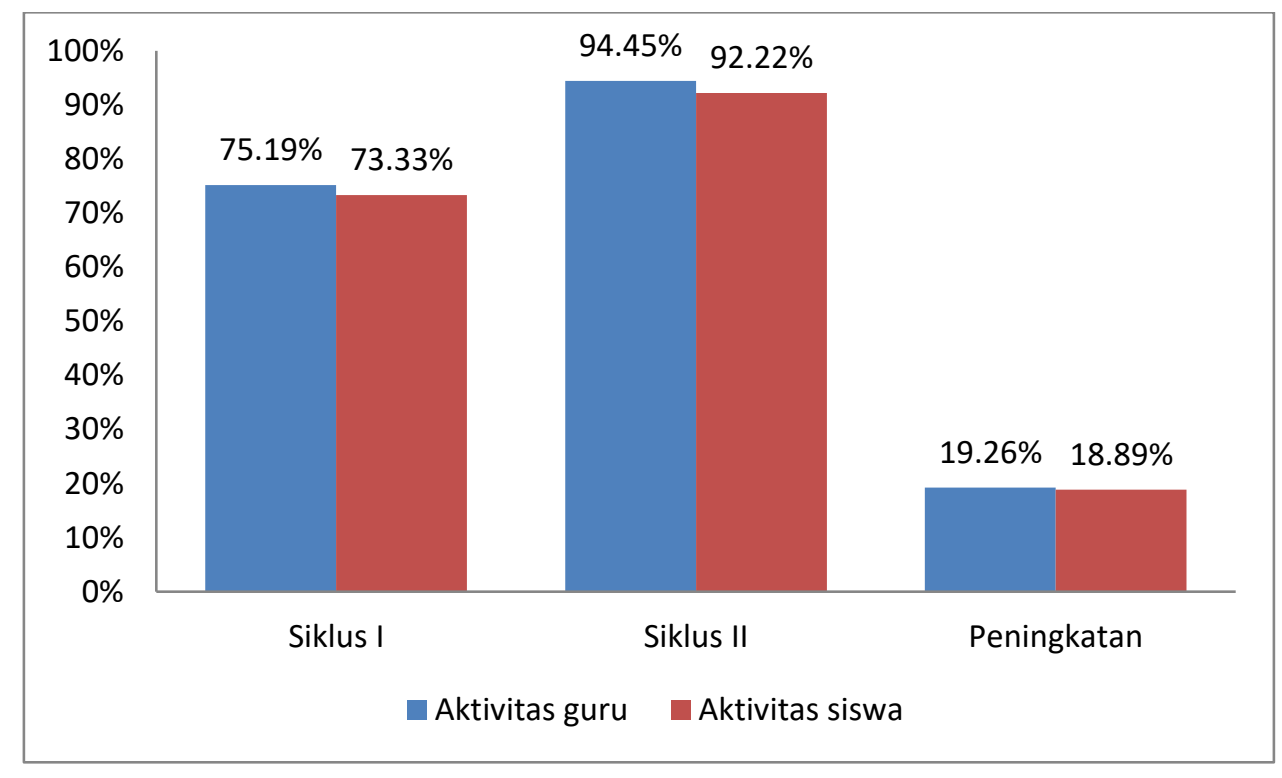

Grafik 4.2 Peningkatan aktivitas guru dan siswa pada setiap siklus

BerdasarkanGrafik 4.2 di atas, diproleh hasil aktivitas guru pada siklus I 75,19\% menjadi 94,45\% pada siklus II sedangkan aktivitas siswa pada siklus I 75,27\% menjadi 92,22\% pada siklus II. Hal ini menujukkan bahwa proses pembelajaran yang dilaksanakan menggunakan model pembelajaran Snowball Throwing pada materi materi daur hidup hewan sangat baik dalam menunjang pembelajaran di kelas. 


\section{Respon siswa pada}

Respon siswa terhadap pelaksanaan pembelajaran dengan guru membimbing siswa mengkaji hubungan antar data yang telah diperoleh dari hasil pengamatan "senang". Guru membimbing siswa mengambil keputusan memecahkan masalah yang paling tepat berdasarkan pengamatan yang telah dilakukan "senang". Guru membimbing siswa melaksanakan pemecahan masalah secara bertahap berdasarkan berbagai sumber serta data hasil pengamatan yang diperoleh mengenai materi yang dipelajari "senang" dapat dilihat pada Tabel 4.10 sebagai berikut:

Tabel 4.10. Hasil respon siswa pada materi daur hidup hewan

\begin{tabular}{ccc}
\hline Respon Siswa & Senang & Tidak Senang \\
\hline Rata-Rata & $72,69 \%$ & $37,31 \%$ \\
\hline
\end{tabular}

Berdasarkan hasil respon siswa yang diperoleh bahwa pada kategri senang diperoleh presentase sebesar $72,69 \%$ dan tidak senang sebesar $23,31 \%$. Untuk lebih memahami dapat diperhatikan grafi berikut ini:

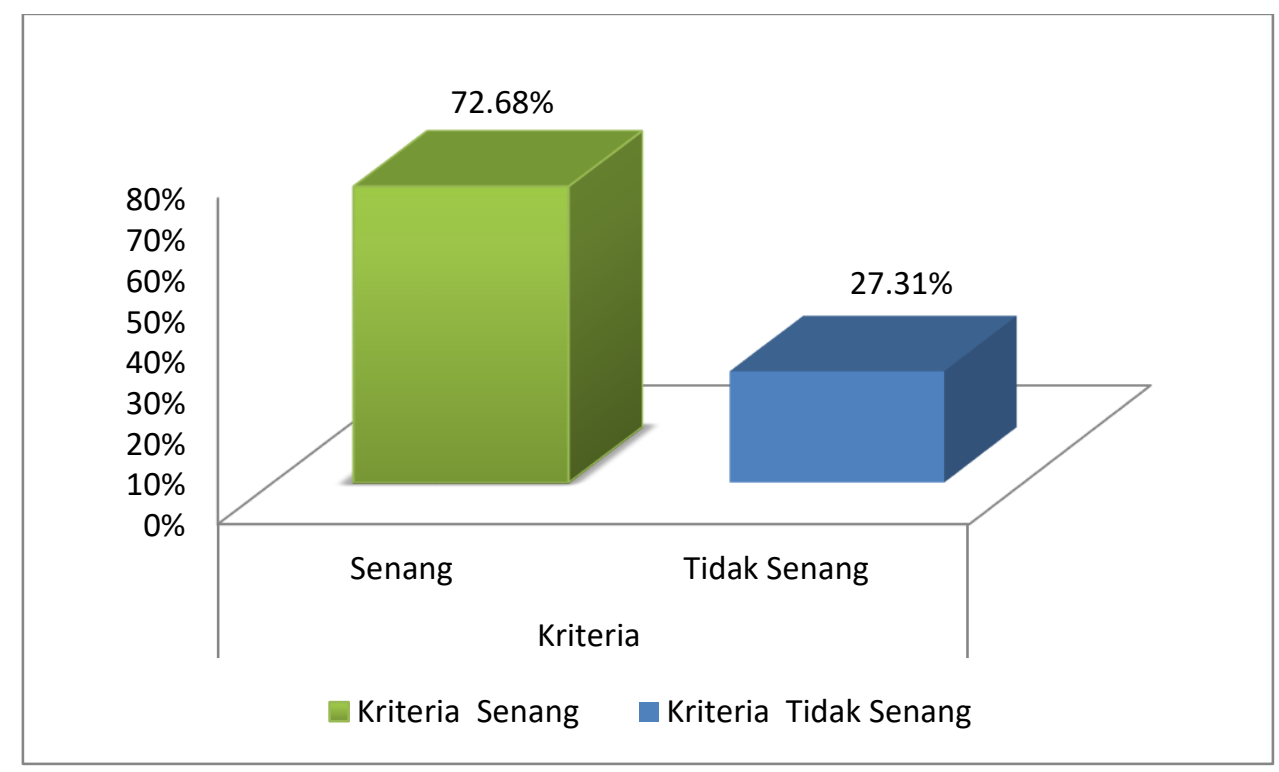

Grafik 4.3 respon siswa pada materi daur hidup hewan

Hasil respon siswa pada model pembelajaran Snowball Throwing pada materi materi daur hidup hewan sudah sangat baik ini terlihat dari persentase senang pada jawaban angket yang diberikan guru sebesar 72,69\% sedangkan tidak senang sebesar $23,31 \%$. 


\subsection{Pembahasan}

Implementasi model pembelajaran model pembelajaran Snowball Throwing pada siklus I dan siklus II telah dilaksanakan dengan baik, serta memberikan perbaikan yang positif dalam diri siswa. Hal ini dapat pada didasarkan temuan pada saat melakukan penelitian dengan mengimplementasi yang telah dilakukan. Siswa mengalami peningkatan dalam memahami materi yang diajarkan dan juga dapat meningkatkan keaktifan, kreatifitas, dan perhatian siswa dalam belajar. Siswa yang semula pasif menjadi aktif dalam mengikuti pembelajaran ilmu pengetahuan alam (IPA) khususnya pada materi sistem pernapasan. Model pembelajarn kooperatif tipe Snowball Throwing ini dipandang sebagai proses pembelajaran yang aktif. Peserta didik lebih banyak belajar melalui proses pembentukan dan penciptaan kerja dalam kelompok dan berbagi pengetahuan serta tanggung jawab individu tetap merupakan kunci keberhasilan pembelajaran.

Hasil ketuntas belajar siswa pada siklus I diperoleh 64,52\% dan siklus II diperoleh $87,10 \%$ mengalami peningkatan sebesar 30\%. Diperoleh bahwa proses pembelajaran yang dilaksanakan menggunakan model pembelajaran Snowball Throwing dapat meningkatkan hasil belajar siswa pada materi daur hidup hewan. Hasil aktivitas guru pada siklus I 75,197\% menjadi 94,45\% pada siklus II sedangkan aktivitas siswa pada siklus I 75,27\% menjadi 92,22\% pada siklus II. Hal ini menujukkan bahwa proses pembelajaran yang dilaksanakan menggunakan model pembelajaran Snowball Throwing pada materi materi daur hidup hewan sangat baik dalam menunjang pembelajaran dikelas. Pada aktivitas guru dan siswa selama proses pembelajaran yang diterapkan menggunakan model pembelajaran Snowball Throwing pada materi materi daur hidup hewan. Hasil respon siswa pada model pembelajaran Snowball Throwing pada materi materi daur hidup hewan sudah sangat baik ini terlihat dari persentase senang pada jawaban angket yang diberikan guru sebesar 72,69\% sedangkan tidak senang sebesar 23,31\%.

Berdasarkan penelitian yang dilakukanMaftuhah Nurul Jannah (2010) Penerapan Model Pembelajaran Snowball Throwing Dalam Upaya Meningkatkan Hasil Belajar Biologi Siswa Kelas VIII MTs. Al-Khoiriyyah I Semarang Pada materi Pokok Sistem Pencernaan.Hasil penelitian menunjukkan bahwa: 1) Langkah-langkah penerapan model pembelajaran Snowball Throwing pada materi pokok sistem pencernaan dapat meningkatkan hasil belajar siswa kelas VIII MTs. Al-Khoiriyyah I, yang disusun dalam bentuk Rencana Pelaksanaan Pembelajaran yang memuat lagkah-langkah proses pembelajaran yang mencirikan model pembelajaran 
Snowball Throwing. 2) Hasil belajar biologi siswa melalui penerapan model pembelajaran Snowball Throwing mengalami peningkatan, khususnya pada materi pokok sistem pencernaan. Pada siklus I diperoleh nilai rata-rata 11,3 dengan ketuntasan belajar $71 \%$ dan meningkat menjadi 9,0 dengan ketuntasan belajar 87,10\% pada siklus II. Sehingga bisa disimpulkan bahwa terjadi peningkatan nilai rata-rata dari siklus I ke siklus II sebesar 19\%, sehingga tidak perlu dilakukan siklus ke III.

Dengan pembelajaran ini konsep materi lebih mudah untuk dipahami oleh siswa. Hal ni sejalan dengan pendapat Slavin yang menyatakan pembelajaran kooperatif membantu siswa memahami pengetahuan, konsep, kemampuan, dan pemahaman yang nantiya mereka butuhkan supaya bisa menjadi anggota masyarakat yang bahagia dan memberikan kontribusi selain itu pebelajaran kooperatif juga mamapu meningkatkan pestasi belajar siswa dan menumbuhkan sikap kerjasama, toleransi, menghargai pada diri siswa. Selain peningkatan hasil belajar, peneliti dibantu observer telah marekam aktifitas perkembangan peneliti dan siswa pada setiap tindakan. Prosentase aktifitas peneliti dan aktifitas siswa mengalami peningkatan pada setiap siklus yang diberikan. Semua aktifitas peneliti dan aktifitas siswa mencapai kriteria sangat baik, sehingga tidak perlu diadakan pengulangan siklus. 


\section{BAB 5. PENUTUP}

\subsection{Simpulan}

Dari pelaksanaan penelitian yang dilaksanakan di SD Negeri 3 Bireuen dapat disimpulkan bahwa:

1. Hasil ketuntas belajar siswa pada siklus I diperoleh $64,52 \%$ dan siklus II diperoleh $87,10 \%$ mengalami peningkatan sebesar $30 \%$. Diperoleh bahwa proses pembelajaran yang dilaksanakan menggunakan model pembelajaran Snowball Throwing dapat meningkatkan hasil belajar siswa pada materi daur hidup hewan.

2. Hasil aktivitas guru pada siklus I $75,197 \%$ menjadi $94,45 \%$ pada siklus II sedangkan aktivitas siswa pada siklus I 75,27\% menjadi 92,22\% pada siklus II. Hal ini menujukkan bahwa proses pembelajaran yang dilaksanakan menggunakan model pembelajaran Snowball Throwing pada materi materi daur hidup hewan sangat baik dalam menunjang pembelajaran di kelas.

3. Hasil respon siswa pada model pembelajaran Snowball Throwing pada materi materi daur hidup hewan sudah sangat baik ini terlihat dari persentase senang pada jawaban angket yang diberikan guru sebesar 72,69\% sedangkan tidak senang sebesar 23,31\%.

\subsection{Saran}

Adapun hal-hal yang ingin disarankan oleh penulis yang berhubungan dengan pelaksanaan penelitian adalah sebagai berikut:

a. Bagi guru, agar mempertimbangkan penerapan model pembelajaran kooperatif tipe Snowball Throwing dalam rangka meningkatkan kualitas pembelajaran dan pemahaman (kemampuan hasil belajar dan kreativitas IPA). Mengingat, model pembelajaran kooperatif tipe Snowball Throwingini dapat meningkatkan proses pembelajaran yang dilakukan guru dalam membelajarkan IPA. Agar model pembelajaran kooperatif tipe Snowball Throwing ini dapat terlaksana dengan baik, maka guru harus : a) Menguasai materi pelajaran. b) Memahami model pembelajaran kooperatif tipe Snowball Throwing.

b. Bagi siswa, agar dapat meningkatkan aktivitasnya dalam kegiatan pembelajaran agar terjadi pembelajaran yang berfokus pada siswa atau student centered. Dengan demikian apabila aktivitas siswa ini terjadi seperti yang diharapkan maka pastinya akan meningkatkan kualitas pembelajaran. 
c. Bagi sekolah, agar mendukung terhadap perkembangan inovasi pembelajaran yang telah dilakukan guru guna perbaikan pembelajaran dalam rangka 24 meningkatkan kualitas pembelajaran dalam hal ini kemampuan hasil belajar dan kreativitas IPA siswa. 


\section{DAFTAR PUSTAKA}

Arikunto. 2010. Penelitian Tindakan Kelas. Jakarta: Bumi Aksara

Aqib, Z. dkk. 2009. Penelitian Tindakan Kelas untuk Guru. Bandung: Yrama.

Dewi Puspita. 2013. Pengaruh Model Pembelajaran Snowball Throwing Terhadap Hasil Belajar Ipa Siswa Kelas V SD Di Gugus Sri Kandi Kecamatan Denpasar Timur. Artikel. Jurusan PGSD, FIP Universitas Pendidikan Ganesha Singaraja, Indonesia. Hal 1-10

Fauzi, A. 2004. Ekonomi Sumberdaya Alam dan Lingkungan. Bandung: PT. Gramedia.

Ismail. 2009. Onset Dan Intensitas Estrus Kambing Pada Umur Yang Berbeda. J. Agroland. 16 (2): $180-186$.

Kunandar. 2013. Penilaian Autentik (Penilaian Hasil Belajar Peserta Didik Berdasarkan Kurikulum 2013) Suatu Pendekatan Praktis. Jakarta: Raja Grafindo Persada.

Lukman. 2009. Peran Hormon Dalam Metamorfosis Serangga (Hormone Role in Insect Methamorphosis). Biospecies Volume 2 No. 1, Januari 2009, hlm 42 - 45

Mulyasa. 2009. Praktik Penelitian Tindakan Kelas. Bandung. Rosda Karya.

Moleong. 2005. Metodologi Penelitian Kualitatif. Bandung: Remaja Rosdakarya

Nadifah, dkk. 2016. Identifikasi Larva Nyamuk Pada Tempat Penampungan Air Di Padukuhan Dero Condong Catur Kabupaten Sleman. Jurnal Kesehatan Masyarakat Andalas. Vol. 10, No. 2, Hal. 172-178

Nurcahyo, dkk. 2014. Identifikasi Toksoplasmosis Pada Feses Kucing Secara Mikroskopis Dan Serologis. Jurnal Kedokteran Hewan Vol. 8 No. 2. Hal. 147-150

Yuliarti, Nurheti., 2007. Awas Bahaya di Balik Lezatnya Makanan. Yogyakarta: Penerbit Andi.

Purwanto. 2011. Evaluasi Hasil Belajar: Yogyakarta: Pustaka Belajar

Suprijono. 2009. Cooperative Learning. Yogyakarta: Pustaka Belajar

Surya. 2015. Strategi Kognitif dalam Proses Pembelajaran. Bandung: Alfabeta

Sheizan. 2007 (6 Januari). Pengertian Biologi Forum SMPN 2 Bandung. Tersedia di: http://smpn2bdg.gettalk.net/t12-pengertian-biologi [1 Agustus 2017]

Syah M, 2015. Psikolgi Belajar. Jakarta: Raja Grafindo Persada

Syuri. 2011. IPA aktif. Jakarta: Esis

Wijayanti, dkk. 2014. Meningkatkan Minat dan Prestasi Belajar Matematika dengan Model Pembelajaran Grup Investigation. Jurnal Pendidikan Matematika UNION 2(1): 55-60. 
Wahyuningsih. 2012. Model Pembelajaran Snowball Throwing Dan Hasil Belajar Pokok Bahasan Pedosfer Siswa Kelas X SMAN 1 Pule Kabupaten Trenggalek. Artikel. Pendidikan Geografi, Fakultas Ilmu Sosial, Universitas Negeri Malang. Email: adiktriwahyuningsih@gmail.com. Hal 1-14. 